\title{
Barcelona
}

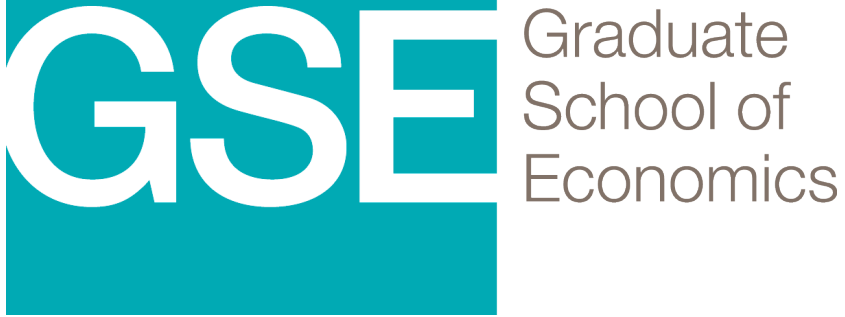

\section{Teaching Styles and Achievement: Student and Teacher Perspectives}

Ana Hidalgo-Cabrillana

Cristina Lopez-Mayan

December 2015

Barcelona GSE Working Paper Series

Working Paper $n^{\circ} 869$ 


\title{
Teaching Styles and Achievement: Student and Teacher Perspectives*
}

\author{
Ana Hidalgo-Cabrillana \\ Universidad Autonoma de Madrid
}

\author{
Cristina Lopez-Mayan ${ }^{\dagger}$ \\ Universitat Autonoma de Barcelona \& BGSE
}

December 18, 2015

\begin{abstract}
Using data from a Spanish assessment program of fourth-grade pupils, we analyze to what extent using traditional and modern teaching styles in class is related to achievement in maths and reading. As a novelty, we measure in-class work using two different sources of information -teacher and students. Our identification strategy relies on between-class within-school variation of teaching styles. We find that modern practices are related to better achievement, especially in reading, while traditional practices, if anything, are detrimental. There are differences depending on the source of information: the magnitude of coefficients is larger when practices are reported by students. These findings are robust to considering alternative definitions of teaching practices. We obtain heterogeneous effects of teaching styles by gender and type of school but only when using students' answers. Our findings highlight the importance of the source of information, teacher or students, to draw adequate conclusions about the effect of teaching style on achievement.
\end{abstract}

JEL classification: I20; I21; J24

Keywords: Students and teacher reports; Test scores; Teacher quality; Modern and traditional teaching

\footnotetext{
*Previously circulated under the title: "Teaching Practices and Student Achievement". We are very grateful to valuable comments by seminar attendants at Universidad Carlos III de Madrid, Bank of Spain, Universidad Autónoma de Madrid, Centre for Economic Performance (LSE), SAEe in Palma de Mallorca, EEA-ESEM Congress and WinE Mentoring Retreat in Toulouse, ESPE Conference in Braga, IAAE Conference in London, Encuentro de Economía Aplicada in Gran Canaria, Jornadas de Economía de la Educación in Valencia, IWAEE in Catanzaro, RWI Research Network Conference on the Economics of Education in Berlin. We are very grateful to the Instituto Nacional de Evaluación Educativa for helping us with the database. We also acknowledge financial support from the Fundación Ramón Areces grant (Ayudas a la Investigación en Ciencias Sociales 2012). All errors are our own responsibility.

${ }^{\dagger}$ Corresponding author: clopezmayan@gmail.com, Department of Economics, Edificio B, Campus de Bellaterra, 08193 Cerdanyola del Valles, Barcelona (Spain).
} 


\section{Introduction}

The knowledge acquired during the schooling period is an essential determinant of labor market outcomes and economic growth. ${ }^{1}$ In the production of the student's cognitive achievement it is widely accepted that teachers are an important input (Hanushek and Rivkin (2006), Hanushek (2006) Rockoff (2004) and Rivkin et al. (2005)). However, the general finding that teacher effectiveness, measured through teacher fixed effects, has a significant impact on student achievement contrasts with the lack of consistent evidence of the relationship between observed teacher characteristics -gender, experience, certification- and student achievement (Hanushek and Rivkin, 2006). Among the exceptions, Rockoff (2004) and Rivkin et al. (2005), which find significant effects of teacher experience (although small and concentrated in first years), and Dee $(2005,2007)$ which obtain significant effects of teacher's gender and race. However, the question about what attributes make a teacher more successful than another in enhancing students' performance has not been settled so far.

A recent line of research has shifted the focus from observed teacher characteristics to teaching practices, that is, what teachers actually do in the classroom (Van Klaveren (2011), Schwerdt and Wuppermann (2011), Lavy (2011), Bietenbeck (2014)). These studies show that teaching practices matter for student achievement. However, the evidence is still scarce and not conclusive, especially to identify the best teaching practices. A better understanding of the relationship between inclass work and student outcomes is necessary to guide educational reforms. In the last years, the proposals to reform education in different countries advocate a greater use of modern teaching practices in detriment of a traditional learning style but this recommendation contrasts with the lack of conclusive evidence about the teaching style that leads to better student outcomes.

In this paper we analyze to what extent using traditional and modern teaching styles in class affects student achievement. Broadly speaking, the traditional style is characterized by the use of rote learning and individual work and the modern style is characterized by the use of real-world problem solving and group work. We analyze the effect of traditional and modern styles using two different sources of information about in-class work: the teacher and her students.

We use data from a national assessment program conducted in 2009 in Spain, "La Evaluación General de Diagnóstico" (EGD2009). This program evaluates fourth grade students in several competencies, including the core ones (mathematics and reading). The EGD2009 also collects broad contextual information through questionnaires to students, families, teachers and principals. Importantly, the program is designed to evaluate all students belonging to the same class, and evaluates two complete classes in most schools. Classes in fourth grade are organized around the

\footnotetext{
${ }^{1}$ See, for example, Murnane et al. (1995), Keane and Wolpin (1997), Cameron and Heckman (1993, 1998), Lazear (2003), Chetty et al. (2011a) for the effect of human capital on labor market outcomes; and Hanushek and Kimko (2000) and Hanushek and Woessmann (2012) for the effect of students' test scores on economic growth.
} 
main teacher, the tutor, who teaches most of the subjects, including usually maths and reading. ${ }^{2}$ Students have the same classmates for the entire school day. In addition, EGD2009 allows linking each student with her teacher. Teacher and students answer the same set of questions about teaching practices. We use this information to measure the use of traditional and modern teaching styles in class according to the teacher and to the students. The classification of practices as traditional or modern follows the taxonomy by Zemelman et al. (2005).

Our empirical strategy exploits between-class within-school variation in teaching practices and test scores to identify the effect of different teaching styles on student achievement. This type of analysis is challenging because non-random allocation of students to schools and to classes within school introduces bias in the estimate of teaching practices. By exploiting within-school variation, we deal with bias from between-school sorting. Within-school sorting should not be a major concern in EGD2009 data since Spanish schooling system is neither track-based in primary education, nor characterized by the practice of "teacher shopping" by parents. We conduct an exhaustive analysis that shows no systematic assignment of teachers and students with specific characteristics to the same class. Although classes were formed randomly, the teacher may still adapt her teaching style to the class level finally formed. We neither obtain evidence that supports this behavior. Nevertheless, we control for a rich set of teacher variables (including tutoring activities) and student characteristics in order to minimize potential bias due to unobserved traits.

Few studies have examined the influence of teaching practices on student achievement. Schwerdt and Wuppermann (2011) and Van Klaveren (2011) study the effect of the percentage of time spent in lecture-style teaching using the TIMSS wave of 2003 for US and Netherlands, respectively. Both papers use a between-subject strategy to control for unobserved student traits. Schwerdt and Wuppermann (2011) find that shifting time from problem solving to lecturing results in an increase in student achievement. This result is in line with Brewer and Goldhaber (1997), which conclude that instruction in small groups and emphasis on problem solving lead to lower student test scores. However, Van Klaveren (2011) find no relationship between time lecturing and student performance.

Lavy (2011) analyzes the effect of traditional and modern teaching on student achievement in Israel using panel data of pupils in fifth and eighth grade. His identification strategy is based on the within-school change in exposure to teaching practices among students attending both grades. Lavy (2011) concludes that traditional and modern practices do not necessarily crowd out each other. In particular, practices that emphasize "instilment of knowledge and comprehension", considered as traditional teaching, have a positive effect on test scores, especially of girls and pupils from low socioeconomic backgrounds. "Analytical and critical skills", viewed as modern teaching, have also a high payoff, especially among pupils from educated families.

\footnotetext{
${ }^{2}$ Throughout the paper, we use the terms "teacher" and "tutor" interchangeably.
} 
Bietenbeck (2014) analyzes the effect of traditional and modern teaching practices on maths and science test scores using the TIMSS wave of 2007. He estimates a student fixed-effect model, where identification relies on the different student exposure to teaching practices between maths and science. He concludes that traditional teaching has a positive effect on overall test scores while modern teaching has a statistically insignificant effect. After splitting overall scores by cognitive skills, modern practices have a positive and significant effect on reasoning, while traditional teaching increases knowing and applying skills.

Our work extends beyond those previous papers in the following. First, in contrast to previous literature, we estimate the effect of teaching practices both using the practices reported by the teacher and by her students. Previous works use only one of these sources of information, usually the students. Information reported by students and teachers have different advantages and disadvantages (Goe et al., 2008). Students' reports about teaching are useful because they provide the perspective of students, the recipients of the teaching practices. However, student responses are subject to bias. Students do not know all the aspects of teaching. Pupils may also answer about in-class work influenced by personality characteristics of the teacher or by their grades. In contrast, teacher self-reports have the advantage that teachers know their own abilities, the class context, and how they work in class. However, teacher responses are also subject to potential biases. Teachers may intentionally misreport their practices to adjust them to the "social desired" practices. Teachers may also unintentionally misreport their practices because they believe that they are applying a certain practice when actually they are not. Therefore, since both student's and teacher's responses on teaching practices are self-reported measures with different potential reporting bias, using both sources of information will improve our understanding of the role of teaching practices on student achievement. Goe et al. (2008) recommend assessing teacher effectiveness gathering data from more than one source, especially if one of these sources are students' reports.

Our second contribution is that we analyze the impact of teaching practices on test scores of younger students (fourth grade, around nine years old). As many recent papers show, it is important to understand at the earliest stages how the education process successfully improves student achievement since this influences outcomes later in life (see, for instance, Heckman (2008), and Chetty et al. (2011b)).

Finally, none of the previous studies has analyzed the impact of teacher attributes and teaching practices on student achievement in Spain. It is important to provide evidence on the role of the teacher because of the serious problems faced by the Spanish educational system: high dropout rate (23.5\% in 2013 according to Eurostat) and lack of excellence (as shown by the low performance in PISA).

Estimation results from using students' and teacher's answers show that modern practices are 
related to better student achievement, while traditional teaching, if anything, is detrimental. The magnitude of the coefficients is larger when practices are reported by students. We also show that there are heterogeneous effects across subjects: modern teaching practices are positively related to reading scores, while the relationship is not significant for maths scores. We analyze the sensitivity of these findings to alternative definitions of teaching practices.

We obtain heterogeneous effects after splitting the sample by gender and type of school, but only depending on the source of information. When practices are reported by the teacher, the estimates do not differ for boys and girls, or for public and private schools. When practices are reported by the students, boys do no benefit from using any particular teaching style, while girls gain from modern practices and loose from traditional ones. Also according to students' answers, traditional (modern) practices are related to lower (higher) scores in public schools, while estimates are not significant in private schools.

Regarding observed teacher characteristics, in line with previous literature, pupils' achievement is not correlated to gender or experience. However, unlike previous papers, achievement is negatively correlated with having a teacher with more than three years of college, suggesting a negative selection of those teachers into primary education in Spain.

The rest of the paper is organized as follows. Section 2 describes the database and explains the construction of the teaching measures. Section 3 explains the empirical strategy. Section 4 presents the results and the sensitivity analysis. Section 5 concludes.

\section{Data}

We use data from "La Evaluación General de Diagnóstico", a national assessment program conducted in 2009 by the Instituto Nacional de Evaluación Educativa (INEE), a Spanish institution belonging to the Ministry of Education. This program evaluates competencies of fourth-grade students in several subjects using a standardized test, designed by the INEE following PISA methodology. We focus on the analysis of competencies in the two core subjects, maths and reading. ${ }^{3}$

EGD2009 evaluates 28,708 pupils belonging to 900 schools following a two-stage stratified sampling design. In the first stage, schools are selected with probabilities proportional to their fourth grade enrollment. In the second stage, one or two fourth grade classes of the school are randomly sampled and all students belonging to these classrooms are evaluated. The sample design ensures that assessment results are representative at national and regional level, and by type of school (public/private).

\footnotetext{
${ }^{3}$ The program also evaluates students' competencies on knowledge of the physical world and on civic values. Knowledge of the physical world refers to knowledge about life and health, the Earth and the environment. The civic competence assesses student's understanding of democratic, social and civic values.
} 
The test consists of both multiple-choice questions and constructed-response items, where the latter requires that students generate and write their own answers. Those type of questions are intended to measure facts, analytical skills and critical thinking (INEE, 2009). Student's overall achievement is made available through five plausible values. Like in other assessment programs, for each student, these values are random draws from an estimated proficiency distribution obtained using student answers to the test items and applying the Item Response Theory. Scores were constructed to have mean equal to 500 and standard deviation equal to 100 . However, we standardize scores to have mean zero and standard deviation one in order to interpret coefficients as fractions of a standard deviation.

EGD2009 also collects detailed contextual information through questionnaires to students, families, teachers, and school principals. Students and families report, among other, gender, date of birth, country of origin, household composition, age at starting school, parents' education, parents' labor status, parents' support in doing homework, and whether the student repeated. ${ }^{4}$

The teacher questionnaire is answered by the tutor of the class. In Spain, fourth grade students have a teacher, the tutor, who teaches most of the subjects, including the core ones (maths and reading). Pupils have the same classmates for the entire school day. It is also usual that students are assigned to a class in first grade and they continue with the same classmates until the end of primary education (sixth grade). Apart from the relatively standard set of variables (gender, experience, degree, training), the tutor questionnaire provides rich information on the practices and materials used in class work, subjects taught, and tutoring activities.

The original sample contains 28,708 pupils distributed into 1,358 classrooms in 900 schools. From this initial sample, we drop (i) students with missing maths or reading scores; (ii) classes with less than five pupils; (iii) students and teachers with blank questionnaires; (iv) teachers who do not teach maths nor reading, so we are sure that teachers in the final sample teach the subjects we analyze; (v) students and teachers with missing information in basic observed variables (gender, country of origin, parents' education and labor status, household composition, experience, type of teacher's degree $)^{5}$; (vi) teachers with missing information on teaching items. As we discuss later, since our identification strategy relies on within-school variation, we do not keep in the sample schools with one sampled class. The final sample contains 11,774 students from 716 classrooms and 358 schools. We check that the final sample is still representative of the target population of fourth-grade students in Spain (there are not significant differences in the distribution of characteristics from initial and final samples).

\footnotetext{
${ }^{4}$ Regarding household composition we construct two categories: living in single-parent household, and living with siblings. Regarding parents' education, we distinguish the following categories for both parents: primary or less, compulsory, high school, vocational training, and university. Regarding parents' labor status, we construct the following categories: self-employed, employee, unemployed, and inactive.

${ }^{5}$ Since we do control for both parents' education and labor status, we do not use information on home resources to avoid dropping too many individuals from the initial sample.
} 
Table 1 presents statistics describing fourth grade teachers in primary school in Spain. They are mainly women, with more than thirty years of experience, teaching mathematics and reading in classes with sixteen students on average. ${ }^{6} 74 \%$ are tutors of the same class in third grade. $17 \%$ hold more than a three-years university degree (five-years degree, master or $\mathrm{PhD}$ ), which is the minimum education level required by law to teach in primary education. Many teachers respond to have participated in some type of training in the last two years, although these variables present quite missing responses. Regarding tutoring work, teachers meet with parents an average of three times per school year, and it is more usual that the tutor asks for meetings. The characteristics of the learning environment and disciplinary climate are captured by the proportion of warning letters about student's behavior sent to her family, and by the percentage of warnings about temporary class suspension.

Table 2 reports descriptive statistics of student characteristics. Around half of fourth-grade pupils are girls and 5\% has repeated at least once. $7 \%$ live in single-parent households and most students live with at least one sibling. The proportion of non-Spanish pupils is $7 \%$, coming mainly from Non-Western Europe and Latin America. A high percentage started school with three years old or less, which is the usual age to start school in Spain. Schooling attainment of mothers and fathers is similar, while the proportion of unemployed or inactive mothers is higher than the proportion of fathers.

Average reading and mathematics test scores are similar for the full sample (Table 3). Differences appear by gender and type of school. On average, girls perform better than boys in reading, while boys perform better in maths. Average scores are larger in both subjects for students in private schools.

\subsection{Teaching practices and materials}

Information about teaching practices is derived from the question, "How often do you use the following teaching practices in your lessons this school year?". On a point-four scale, possible answers are "Never or almost never", "Sometimes", "Almost always", and "Always". Teachers respond about each of the following practices: (a) "Most of the time I teach by telling", (b) "Students present works or topics to classmates", (c) "While I teach, I ask students questions about the lesson", (d) "While I teach, students ask me doubts", (e) "I promote discussions", (f) "Students work on exercises and activities proposed by me", (g) "Students work individually", (h) "Students work in small groups", (i) "I give different exercises or activities to best/worst students". We do not consider this last item in the analysis because it reflects the level of students in class, leading to a problem of reverse causality in the estimation. According to the taxonomy by Zemelman et al. (2005), practices (b), (e), and (h) can be classified as modern, and practices (a),

\footnotetext{
${ }^{6}$ Class size is the total number of surveyed students in a class in the initial sample.
} 
(f), and (g) as traditional. However, it is not possible to unambiguously match items (c) and (d) as traditional or modern. In principle, item (c) may be thought as traditional and item (d) as modern, but it is also possible the other way around.

EGD2009 data supports this classification. Table 5 shows correlation coefficients among tutor's answers to all items. Modern items (b), (e), and (h) are positively correlated (with coefficients around 0.26). The same pattern appears for traditional items (a), (f), and (g), with coefficients ranging from 0.13 to 0.30 . Items (d) and (c), classified as modern and traditional, respectively, present a positive, but smaller, correlation with the respective modern and traditional items. At the same time, item (c) is positively correlated with modern items, and item (d) with traditional ones, while this pattern is not observed for the rest of items (see bottom left of the Table). Moreover, these two items are correlated with a coefficient equal to 0.46. Consistently with Zemelman et al. (2005)'s taxonomy, it is difficult to unambiguously classified items (c) and (d), and we exclude them from the baseline measure of teaching practices (see final classification in Table 4). In Section 4.2 we check the robustness of the results to include items (c) and (d).

For the ease of interpretation, we rescale answers to each item by assigning a proportional value as follows: 0 to "Never or almost never", 0.34 to "Sometimes", 0.67 to "Almost always", and 1 to "Always". In this way, responses are interpreted as the proportion of the time used in that activity. The aggregate measure of traditional teaching practices is the mean of the teacher's answers to items (a), (f) and (g); and the aggregate measure of modern teaching practices is the mean of the teacher's answers to items (b), (e) and (h).

Information about teaching materials is derived from the question, "How often do you use in your lessons the following materials?". Using the same possible answers as in question 21, teachers respond about: (a) textbook, (b) workbook, (c) books from school library, (d) your own materials, (e) newspapers, (f) computers and internet, (g) audiovisual aids. We assign the proportional values $0,0.34,0.67$, and 1 , to each item. The traditional index is constructed by averaging teacher's answers to items (a) and (b), and the modern index is constructed as the mean to items (f) and (g).

The EGD2009 survey asks students the same questions about practices and materials. In particular, the question about practices is "In general, how is in-class work?". Possible answers correspond exactly with items (a) to (h) from the teacher questionnaire and they are coded using the same scale. It should be noted that the question to students is about all class work and, although the tutor teaches most subjects, student's answers might refer to another teacher. The question on teaching materials is "How often do you use in the lessons the following materials?", and possible items are the same included in the teacher's question (except item (d)). Assigning the same proportional values $(0,0.34,0.67,1)$, and using the same classification, we construct modern and traditional measures of teaching practices and materials by averaging students' responses at 
class level (excluding the student's own response).

As explained in Introduction, using students' and teacher's answers have different advantages and disadvantages. However, since they are self-reported measures with different potential reporting bias, it is advisable to use more than one source, especially if one of these sources are students' reports. So, unlike previous literature, which uses only one source of information, usually the students, we estimate the relationship between teaching style and achievement by measuring the teaching style according to the perspectives of teacher and students.

Table 6 contains the average and standard deviation of modern and traditional indexes constructed with tutor's and students' answers. On average, teachers report an use of traditional and modern practices for $66 \%$ and $43 \%$ of class time, respectively. The proportion of the time using traditional or modern materials is similar (65\% and $34 \%$ respectively). Average pupils' answers are close to tutors' response: students slightly underreport modern teaching and materials, and overreport traditional teaching, but not traditional materials. To gain further insight about to what extent students' answers differ from tutor's ones, we calculate the gap in the indexes of the tutor and each of her students. Then, we average those gaps at class level to obtain the distribution of the within-class differences in teacher and student indexes. Figure 1 shows histograms of this distribution and Table 8 present some descriptive statistics. Figure 1 shows that the average gap in each index is small because positive and negative differences in students' and tutor's index compensate each other across classes (symmetric distribution of differences). In other words, within each class, students' answers do differ from her tutor's responses, but without a clear positive or negative pattern for the whole sample.

As we explain in Section 3, we estimate separately using tutor's and students' responses. In each specification, we include jointly traditional and modern indexes. In order to interpret the effects, we should note that the two measures do not imply a trade-off between using traditional or modern methods in class. The estimated coefficient of one of the indexes should be interpreted as the effect on test scores holding constant the other index. In this way, we do not restrict the possibility that some teaching practices can be conducted, at least to some degree, simultaneously, even if one practice is traditional and another is modern ${ }^{7}$. For instance, one possible activity proposed by the teacher (item (f), traditional) may be to promote discussions in class (item (e), modern). So, the two practices would happen simultaneously. Indeed, Table 5 shows a positive correlation between these two items. Nevertheless, we assess the sensitivity of our results to construct a new measure of teaching practices that imposes that the time using traditional or modern activities must not violate the time budget constraint.

Table 7 shows that the correlation between traditional and modern practices indexes is not significantly different from zero. This is the result of negative and positive correlations across

\footnotetext{
${ }^{7}$ Note that questions about practices and materials do not impose either any restriction of this type.
} 
individual items that may compensate each other (see bottom left of Table 5). The correlation between traditional and modern materials indexes is not zero, but small (0.11). For indexes constructed with tutor's information, the correlation between modern practices and materials is 0.22 and between traditional practices and materials is 0.36 , both statistically significant at one percent level. Those correlations are a bit higher for the students indexes. Correlation among tutor's and students' answers is positive and significant, ranging from 0.10 to 0.24 (see matrix in the left bottom of Table 7). A positive correlation reflects that students' and tutor's answers go in the same direction. However, the small correlation is evidence that pupils and tutor's perception is far from identical.

Finally, Table 9 presents the overall, between- and within-school variance in teaching practices and materials. Not surprisingly, most of the variation in teaching practices appears between schools. However, a non-negligible amount still happens within a school (around one third). Between-class variation in the use of different materials is smaller according to tutor (21\%-23\%), but larger according to students (35\%-41\%).

\section{Empirical Strategy}

The effect of traditional and modern teaching on student achievement can be estimated using the following education production function:

$$
y_{i c s}=\alpha+\gamma^{\prime} T I_{c s}+\lambda^{\prime} T_{c s}+\beta^{\prime} X_{i c s}+\phi_{s}+\varepsilon_{i c s}
$$

where $y_{i c s}$ is the standardized test score of student $i$ in class $c$ at school $s . T I_{c s}$ is the vector of traditional and modern teaching indexes in class $c$ in school $s$ (ModTI $\left.I_{c s}, \operatorname{TradTI}_{c s}\right)$. We estimate two specifications, one with modern and traditional practices indexes, and another with modern and traditional materials indexes. In turn, we run separate regressions for the indexes constructed using the tutor's and the students' answers ${ }^{8} . T_{c s}$ is a vector of tutor variables and class size. $X_{i c s}$ is a vector of student characteristics. $\phi_{s}$ is a school fixed effect and $\varepsilon_{i c s}$ is the error term.

The identifying assumption of the effect of traditional and modern teaching on student achievement $(\gamma)$ is that teaching practices (and materials) are uncorrelated with the error term conditional on the other regressors. One of the potential confounding factors is the endogenous selection of students and teachers across schools. This between-school sorting will happen if, for instance, students attending a school present specific characteristics as a consequence of the nonrandom choice of neighborhood by parents. Related to this, some parents may prefer a school that hires teachers with some specific characteristics or that has certain teaching philosophy. To deal with this endogenous selection of students and teachers we focus on schools with two sampled classes

\footnotetext{
${ }^{8}$ Note that when we use the students' answers, the indexes are constructed excluding the student's own answer $\left(\operatorname{ModT} I_{c s-i}, \operatorname{TradTI}_{c s-i}\right)$
} 
and include school fixed effects. Therefore, in this approach identification of $\gamma$ relies on betweenclass within-school variation in teaching styles and test scores. This requires enough within-school variation in data (school fixed effects account for between-school variation). As shown in Table 9, an important proportion of total variation in teaching styles happens across classes within school.

Even after accounting for between-school sorting, there may be still unobserved student and teacher traits ( $\mu_{i c s}$ and $\eta_{c s}$, respectively) in the error term that may bias the estimate of $\gamma$. In particular, $\gamma$ would be biased:

- If there is some student unobserved trait that has a direct effect on $y_{i c s}$ while it is correlated with the teaching style. That is, $\gamma$ would be biased if $\operatorname{corr}\left(\mu_{i c s}, T I_{c s}\right) \neq 0$. This would happen if there is sorting of students to classes within school (so, the ability composition of the two classes will be different) and the teacher adapts her teaching practices to the resulting level of ability in the class (reverse causality). For example, if high-ability students are assigned to the same class and the teacher decides to increase the use of modern practices with that class, the estimate of $\gamma$ will be biased. It is important to note that although $\mu_{i c s}$ affects scores, if students are more or less randomly assigned to classes, and teachers do not adapt their teaching style to the ability of the class, $\gamma$ will not be biased.

- If there are unobserved teacher traits that have a direct impact on $y_{i c s}$, while they are correlated with the teaching style. That is, $\gamma$ would be biased if $\operatorname{corr}\left(\eta_{c s}, T I_{c s}\right) \neq 0$. This would happen if unobserved teacher ability or motivation affect the choice of the teaching style, while they have a direct effect on student test scores, aside from the effect through the teaching style.

\subsection{Within-school selection of students and teachers}

As discussed above, if the teaching style is correlated with $\mu_{i c s}$ and $\eta_{c s}$ within-school, the estimate of $\gamma$ will be biased. This correlation may appear as a result of non-random assignment of students and teachers to classes within-school. For instance, within-school sorting arises if parents "buy" the teacher assigned to the class. In our analysis, this source of selection is not a concern because "teacher shopping" is absent or very rare in Spain. We also should note that in primary education in Spain there is not an explicit rule to assign students to classes because the system is not trackbased. However, we cannot disregard that within-school sorting does not exist because a school principal still may decide to assign students to classes, or teachers, following a non-random rule. For example, we will obtain biased estimates if ability is used to assign students to classes, and, then, the teacher decides to adjust her teaching style to the final ability level in the class. Another concern is whether more motivated or able teachers choose a certain teaching style. To assess to what extent these issues can be a problem in EGD2009 data, we conduct the following analysis. 
First, we investigate whether students with certain family characteristics are more likely to be in classes with certain type of teacher. To this end, we regress observed teacher variables on sociodemographic characteristics of students measured at class level:

$$
t_{c s}=\alpha_{0}+\alpha_{1}^{\prime} X_{c s}+\phi_{s}+v_{i c s}
$$

where $t_{c s}$ is a characteristic of the tutor of class $c$ in school $s ; X_{c s}$ is a vector of sociodemographic characteristics of class $c$ at school $s$; and $\phi_{s}$ is a school fixed effect. Table 10 reports the results. Each column represents a separate regression. The variables that capture the sociodemographic characteristics of the class are parents' education, parents' employment, and percent of: non-Spanish, students with siblings, living in single-parent household, female, and repeater. With respect to teacher variables, we consider gender, years of experience, holding a five-years university degree, taught subjects (maths and reading, only reading), and tutor in third and fourth grades. Last two columns present the results from regressing modern and traditional teaching practices on class-level variables. We do not find a systematic within-school relationship of teacher characteristics and teaching practices with class-level variables. That is, no relationship with proportion of non-Spanish, percentage of repeaters in class, students from low-educated families, etc. We also check the joint significance of regressors with an F-test (last rows of Table 10). In all regressions, F-statistics do not reject the null hypothesis that the joint effect of class-level characteristics is zero at five percent level.

Second, we analyze whether classes that differ in teaching practices, differ in pupils' characteristics as well. For this purpose, following Lavy (2011), we regress student-level variables on modern and traditional teaching practices, and school fixed effects:

$$
x_{i c s}=\beta_{0}+\beta_{1}^{\prime} T P_{c s}+\phi_{s}+\varphi_{i c s}
$$

where $x_{i c s}$ is the characteristic of student $i$ in class $c$ at school $s, T P_{c s}$ is the vector of modern and traditional indexes of teaching practices, and $\phi_{s}$ is a school fixed effect. Student characteristics are: parents' education, parents' labor status, living in single-parent household, living with siblings, gender, repeater and non-Spanish origin. Table 11 presents the results. For each panel, each column represents a separate regression. Neither traditional nor modern teaching practices are systematically correlated with student characteristics. In most regressions, the effect of teaching practices is not significantly different from zero. In addition, F-statistics do not allow rejecting the null hypothesis that the effect of traditional and modern practices is jointly zero. Thus, conditioning on the school, we conclude that students with certain characteristics are not more likely to be assigned to teachers using certain practices.

To sum up, evidence from Tables 10 and 11 does not show a systematic within-school assignment of students with certain characteristics to certain type of teachers. However, even though 
classes are formed more or less randomly, they may receive other school resources differently. For instance, a teacher with a specific teaching style may be assigned to classes of certain size. To check this, we run

$$
t p_{c s}=\lambda_{0}+\lambda_{1} s i z e+\lambda_{2} s i z e^{2}+\phi_{s}+\varsigma_{i c s}
$$

where $t p_{c s}$ denotes teaching practices (traditional or modern); size is class size and $\phi_{s}$ is school fixed effect. Results are shown in Table 12, where each column represents a separate regression. Columns one and three do not include school fixed effects. Individual and joint significance of class size and class size squared does not show systematic correlation between these variables and teaching practices, especially after conditioning on school.

Finally, we regress traditional and modern teaching practices on tutor variables, class size and school fixed effects:

$$
t p_{c s}=\theta_{0}+\theta_{1}^{\prime} T_{c s}+\theta_{2} s i z e+\phi_{s}+\psi_{i c s}
$$

The purpose of this analysis is to check whether a teaching style (traditional or modern) is correlated with certain teacher characteristics after controlling for school and class size. We consider these tutor characteristics: female, years of experience, holding a five-years degree, taught subjects, whether tutor or parents ask for a meeting, number of meetings with parents, and being tutor of that class in third and fourth grade. Results are in Table 13. Only holding a five-years college degree is significantly correlated with using a traditional style, although only at ten percent level. Any significant association pattern appear for the rest of variables. Moreover, the set of tutor variables and class size is neither jointly significant (see bottom of Table 13). In sum, we do not find evidence that teachers with those observed characteristics self-select into a certain teaching style. Therefore, it is plausible to assume that selection into teaching practices due to unobserved teacher characteristics will not be a big concern.

Evidence from this exhaustive analysis supports that the existence of selection of students or teachers to classes is not a great concern in our analysis. Nevertheless, in order to minimize potential bias from unobserved traits, we still consider a broad set of student and teacher variables in the estimation. The vector of student characteristics $\left(X_{i c s}\right)$ includes gender, country of origin, repeater, mother and father's education, mother and father's labor status, living in single-parent household, living with siblings, born in fourth quarter, age at starting school, whether a private tutor or someone in the family helps a student with homework. Note that this set of controls includes several variables as proxy for unobserved student ability and previous performance (for instance repeater, or parents' education). The vector of tutor characteristics $\left(T_{c s}\right)$ includes, aside from typical controls used in the literature (gender, experience, or type of degree), whether the tutor teaches only maths, only reading or both, and variables capturing teacher's work as tutor (number of meetings with parents, whether tutor or parents ask for a meeting, being tutor of the 
class in third grade). Unobserved teacher effort or ability is captured, although partially, through some of these variables.

Although we cannot rule-out completely the presence of unobserved teacher or student traits, and consequently we have to be cautious in interpreting our estimates as causal, we should note that (i) we conduct an exhaustive analysis showing no evidence of within-school sorting; (ii) we do not find evidence of correlation of teaching practices with observed teacher and class characteristics, so it is plausible to assume that selection on unobservables is neither a big concern; (iii) we include a broad set of regressors to control for possible differences in student background and tutor across classes, once we have accounted for school. Finally, note that the potential problem of endogeneity of teaching variables with test scores in a particular subject is ameliorated because tutor and students answer about teaching practices or materials generally used in class, instead of about the particular teaching style used in maths or reading.

\section{Results}

Table 14 presents results from estimation of regression (1) where $T I_{c s}$ denotes the vector of modern and traditional teaching practices. Table 15 presents estimation results where $T I_{c s}$ is the vector of modern and traditional teaching materials. Results are obtained by pooling maths and reading test scores and including a dummy variable for maths. Standard errors are clustered at school level.

Columns (1) to (3) show the results corresponding to teaching practices reported by tutor, and columns (4) to (6) present the estimates using students' answers. In column (1) and (4), we estimate an specification of regression (1) that includes only the vector of teaching practices, and a maths dummy. In columns (2) and (5), we add class size and teacher characteristics. In columns (3) and (6), we include student characteristics ${ }^{9}$. Using tutor's answers, the effect of modern teaching practices is positive and significant in the most complete specification -including teacher and student control variables. The coefficient is 0.21 , which implies that a $10 \%$ increase in the modern index is associated with a $2.1 \%$ of a standard deviation increase in test scores. The effect of traditional teaching practices is small and not significant. Estimates hardly change after adding teacher and student controls. The coefficients of traditional and modern teaching practices are larger using students' answers than tutor's answers, but, again, only the effect of modern teaching is significant. In the specification involving all covariates, a $10 \%$ increase in the modern index is associated with a $3.4 \%$ of a standard deviation increase in the test score. This effect is robust to adding teacher and student control variables.

Using traditional materials in class is associated with larger scores when the information is reported by the tutor, but with lower ones when the information is reported by students (Table

\footnotetext{
${ }^{9}$ The estimated coefficients of student characteristics are presented in Tables A.1 and A.2 in Appendix.
} 
15). The effect of modern materials is positive, and larger when using students' answers. However, the effect of materials is not estimated with precision in any regression.

In line with previous literature, we do not find strong evidence that pupils' achievement is correlated to observable teacher characteristics, such as gender or experience. The effect of being female is negligible and not significant. Having a teacher with more than five years of experience is associated with higher test scores, although the effect is only significant for teachers with 15 to 19 , or with more than 30 years of experience. We neither find a clear relationship of test scores with taught subjects. Regarding tutoring work, being tutor of the class also in third grade is related to better achievement, but the effect is small and significant at ten percent level only when using tutor's answers. The most interesting effect appears for the type of degree that tutor holds. Teachers with five-years university degree or more are associated to a lower student achievement of 0.08 standard deviations compared to teachers with a three-years college degree. The effect is significant at five percent level and robust across all specifications. Since holding a three-years degree is required to teach in primary education in Spain, the negative effect may suggest that teachers with more years of college are negatively self-selected. That is, they may decide to work as primary education teachers after not finding a job in the private sector and/or in secondary education (where the requirement is to hold at least a five-years college degree). Consequently, those teachers may lack motivation or adequate teaching skills, and this would explain the negative effect that we find. Unlike us, previous works obtain that teachers with more years of education are related to better student performance.

To better understand why we get different estimates of teaching practices depending on whether we use students' or teacher's reports, we analyze to what extent the gap in tutor and student indexes is related to observed characteristics. We regress this gap on teacher and student observed variables, school fixed effects, and dummy for public school. We also include the first plausible values in maths and reading in order to explore whether differences in student and teacher perception are related to student ability -for instance, high achievers may perceive better teacher's work, responding more similar to her. Results are in Table B.1 in Appendix. In general, tutor characteristics are not significantly correlated to the teacher-student gap in practices and materials. With respect to student characteristics, most significant effects appear for modern practices. This may suggest that, for some reason, students find more difficult to perceive modern than traditional practices. A complementary explanation is that students capture well modern practices but tutor's answers have more measurement error because she identifies her teaching style as modern although it is not. Note that being tutor in third and fourth grade reduces the gap in modern practices by 0.04 . This is likely to reflect that students with the same tutor over two years have a better knowledge of her class work, responding closer to tutor's responses. Female, higher plausible values, and higher mother's education are associated to a larger gap in modern 
practices. Repeater, starting school older, and born in Latin America or Asia are related to a lower gap in modern practices. Female and repeater present the reverse correlation with the gap in traditional practices. Attending a public school reduces the gap by 0.33 and 0.17 in modern and traditional practices, respectively. It also reduces the gap in traditional materials. In modern materials, the correlation is positive but small.

Our results provide new insights on the effect of teaching style on achievement. Lavy (2011) finds that both traditional and modern teaching practices have positive effects on test scores, larger for traditional teaching. Bietenbeck (2014) concludes that only traditional teaching has a statistically significant and positive effect on overall test scores. Schwerdt and Wuppermann (2011) find that teachers who spend more time lecturing are associated with higher test scores. In contrast, we obtain that modern teaching is related to better student achievement, while traditional teaching, if anything, is detrimental. Previous evidence is found using only one source of information (teachers in Schwerdt and Wuppermann (2011), and students in Lavy (2011) and Bietenbeck (2014)). Our results show that the sign of the effects obtained with students' answers is consistent with the sign found using tutor's answers, but the magnitude of the coefficients is larger with students' information. These differences suggest that the source of information about in-class work is important for a better understanding of the role of practices on achievement.

\subsection{Heterogeneous effects}

Previous results are obtained assuming that the effects of modern and traditional styles are the same in maths and reading. Now, we explore whether there are heterogeneous effects by subject. Tables 16 and 17 present the results, where columns (1) and (2) show the effect of practices and columns (3) and (4) the effect of materials. We estimate separately for maths and reading instead of using interaction terms for these subjects with teaching variables. Although sample sizes are smaller, the separate approach allows the effect of the rest of variables to differ by subject. The estimates including interaction terms would capture differences in the effect of practices by subject, but also differences in the effect of other variables. Using modern practices in reading is related to better student achievement and the effect is large -a $10 \%$ increase in the modern index is associated with $3.1 \%$ to $4.3 \%$ of a standard deviation increase in test scores. The use of modern practices in maths also is related to higher scores, although the effect is not significant. Applying traditional practices is not significantly related to achievement, except with students' answers, where the effect is large $(-0.32)$ and significant at $10 \%$. Therefore, the overall positive effect of modern practices in Table 14 comes through its impact on reading scores. The relationship between the use of modern or traditional materials and achievement is not significant in maths. In reading, using the information reported by students, modern materials are significantly and strongly associated to scores (coefficient equal to 0.48 ). 
To gain deeper knowledge about the effect of teaching practices on student achievement, we explore whether there are heterogeneous effects by gender (Table 18) and type of school (Table 19). We estimate by splitting the sample by these subgroups. Table 18 shows a gender gap by subject: boys perform better in maths than girls (maths dummy equal to 0.12 in the regression for boys and -0.13 in the regression for girls). However, the estimates of modern and traditional practices do not reveal differences across boys and girls if the tutor reports the practices (Panel A). The picture is quite different when estimates are obtained using students' reports (Panel B). In this case, we find striking differences by gender. For girls, the use of traditional practices is associated to lower scores, while the use of a modern style is related to better achievement. The estimates for boys are smaller and not significant. Looking at each subject separately, we find that this gender gap appears for reading but not for maths.

In Table 19 we stratify the sample by public and private schools. The subsample of private schools include also charter schools. First of all, there is not significant public-private gap by subject (maths dummy is not significantly different from zero). Using tutor's answers (Panel A), estimates hardly differ across public and private schools. Only a positive and significant association between the use of traditional style and maths scores is found in private schools, but not in public schools. Again, the picture obtained using students' answers is different (Panel B). In public schools, the use of traditional practices is associated to lower scores $(-0.34)$ and the use of modern practices to higher scores (0.40). These effects are not significantly different from zero in private schools. By subject, this public-private gap appears in reading but not in maths.

The existence of differences in the effects of teaching styles across gender and type of school if indexes are constructed with students' but not with tutor's answers suggest that those gaps do not reflect real differences in the effects of practices. Instead, they may be the result of differences in the perception of traditional and modern styles for boys and girls, or for students in public schools, which will translate into different answers about teaching practices.

\subsection{Sensitivity analysis}

In this Section, we conduct several sensitivity tests in order to address potential reservations about our findings ${ }^{10}$. In the first set of tests, we assess whether results hold after considering alternative ways of measuring teaching practices. Our preferred regressor simply averages tutor's or students' answers across those practices that can be unambiguously classified as modern or traditional according to both Zemelman et al. (2005)'s taxonomy and observed correlations across items. However, we assess the sensitivity of results to use alternative measures.

The baseline regression includes traditional and modern measures jointly because they do not

\footnotetext{
${ }^{10}$ For the sake of brevity we present results for maths and reading scores. Results from pooling scores are available upon request.
} 
imply a trade-off between using traditional or modern methods in class. Nevertheless, individual correlation between some traditional and modern items is different from zero (see Table 5). Thus, a possible concern is whether including jointly the two measures may create any collinearity problem, which may influence the results. Table 20 shows that findings from the baseline regressions (columns (1), (4), (7) and (10)) do not change compared with results from regressions including each index one at a time.

In Table 21 we assess the robustness of results to include items (c) "While I teach, I ask students questions about the lesson", and (d) "While I teach, students ask me doubts". Baseline measures do not include these items because, as we have discussed, its classification as traditional or modern is ambiguous. In Panel A we redefine the traditional and modern indexes including item (c) as traditional and item (d) as modern, while in Panel B, we consider item (c) as modern and item (d) as traditional. Both panels show that results are similar to baseline findings.

In Table 22, we redefine the measure of teaching practices as the share of class time involved in modern activities. To construct this new measure, we impose that the total class time allocated to the six traditional or modern practices listed in Table 4 must be equal to one. In the baseline measure, we simply rescale the answers to each practice for the ease of interpretation but without imposing any additional restriction. Thus, it is possible that, for a given class, the sum of the traditional and modern indexes is larger than one, violating the time budget constraint. Indeed, using teacher's answers, we observe this in $74 \%$ of the classes. This may reflect that some teaching activities listed in the questionnaire may be simultaneous, at least to some degree. However, it may also reflect measurement error or careless responses (for instance, answering "always" to all items). In order to assess whether our results may be affected by this concern, we rescale the answers of each teacher, and student, such as they sum to one. That is, for each individual we sum the numerical values assigned to the answers of the six items (Section 2.1). Then, we weight each answer by the inverse of that sum. In this way, we keep the relative frequency of use of practices, but without violating the time budget constraint. The share of class time using modern teaching practices is the sum of the time allocated to the three modern items. The rest of the time is for traditional practices. We construct the measure of the share of time using modern materials in the same way. Table 22 show that results are qualitative and quantitative similar to baseline estimates.

Table 23 presents the results from a second type of sensitivity tests based on adding more control variables to the baseline specification. In Panel A we include the class average of student characteristics (excluding the student's own value). Controlling for these regressors hardly changes the effect of practices or materials on student achievement. This supports our previous evidence that there is not within-school sorting. If results were driven by this type of selection, controlling for sociodemographic characteristics of the class would change results. 


\section{Conclusions}

In this paper, we analyze to what extent using traditional or modern teaching styles is related to student achievement in maths and reading in primary education. As a novelty, we measure inclass work using two different sources of information -students and tutor. Analyzing the effect of teaching on student achievement is challenging because schools, and classes within school, are not formed randomly. To deal with this non-random assignment, our identification strategy relies on between-class within-school variation of teaching styles. We also conduct an exhaustive analysis to show that systematic within-school assignment of students or teachers to classes is not a concern.

Results show that modern practices are related to better student achievement, while traditional teaching, if anything, is detrimental. The magnitude of the coefficients is larger when practices are reported by students. By subject, we find that modern teaching practices improve reading achievement, while they are not significant for maths. Results are robust to considering alternative definitions of teaching practices and to controlling for class-average socio-demographic characteristics.

We also explore whether there are heterogeneous effects by gender and type of school. Results differ depending on the source of information. When practices are reported by the teacher, estimates do not differ for boys and girls, or for public and private schools. When practices are reported by the students, boys do no benefit from using any particular teaching style, while girls gain from modern practices and loose from traditional ones. Also according to students' answers, traditional (modern) practices are related to lower (higher) scores in public schools, while estimates are not significant in private schools.

Regarding observed teacher characteristics, pupils' achievement is not correlated to gender or experience, but, unlike previous literature, it is negatively correlated with having a teacher with more years of education. We discuss that this may reflect a negative selection of those teachers into primary education. Spanish educational authorities should take into account this misallocation problem when establishing the degree requirements to teach in primary education.

Our findings about the existence of differences in the effect of the teaching style depending on who reports the information about in-class work are important from a policy perspective. We should note that previous results rely only on one source -usually the students. We discuss that using practices reported by students or teachers have different advantages and disadvantages. However, since both are self-reported measures with different potential reporting bias, using both sources of information will improve our understanding of the role of teaching practices on student achievement, involving better policy recommendations. 


\section{References}

Bietenbeck, J. C. (2014): "Teaching Practices and Cognitive Skills," Labour Economics, in press.

Brewer, D. J. And D. D. Goldhaber (1997): "Why don't schools and teachers seem to matter?" The Journal of Human Resources, 32, 505-523.

Cameron, S. V. And J. J. Heckman (1993): "The Nonequivalence of High School Equivalents," Journal of Labor Economics, 11, 1-47.

_ (1998): "Life Cycle Schooling and Dynamic Selection Bias: Models and Evidence for Five Cohorts of American Males," Journal of Political Economy, 106, 262-333.

Chetty, R., J. Friedman, And J. Rockoff (2011a): "The Long-Term Impacts of Teachers: Teacher Value-Added and Student Outcomes in Adulthood," NBER Working Paper No. 17699.

Chetty, R., J. N. Friedman, N. Hilger, E. Saez, D. W. Schanzenbach, and D. YaGAN (2011b): "How Does Your Kindergarten Classroom Affect Your Earnings? Evidence from Project Star," Quarterly Journal of Economics, 216, 1593-1660.

DeE, T. S. (2005): “A Teacher like Me: Does Race, Ethnicity, or Gender Matter?" American Economic Review Papers and Proceedings, 95, 158-165.

_ (2007): "Teachers and the Gender Gaps in Student Achievement," Journal of Human Resources, 42, 528-554.

Goe, L., C. Bell, And O. Little (2008): "Approaches to Evaluating Teacher Effectiveness: a Research Synthesis," National Comprehensive Center for Teacher Quality.

HanusheK, E. A. (2006): School resources, in Handbook of the Economics of Education, edited by Eric A. Hanushek and Finis Welch. Amsterdam: North Holland, vol. 2, chap. 14, 865-908.

Hanushek, E. A. And D. D. Kimko (2000): "Schooling, labor force quality, and the growth of nations," American Economic Review, 90, 1184-1208.

HanusheK, E. A. And S. Rivkin (2006): Teacher Quality, in Handbook of the Economics of Education, edited by Eric A. Hanushek and Finis Welch. Amsterdam: North Holland, vol. 2, chap. 18, 1051-1078.

Hanushek, E. A. And L. Woessmann (2012): "Do better schools lead to more growth? Cognitive skills, economic outcomes, and causation," Journal of Economic Growth, 17, 267-321.

Heckman, J. J. (2008): "Schools, Skills and Synapses," Economic Inquiry, 46, 289-324. 
INEE (2009): "Evaluación General de Diagnóstico 2009. Marco de la evaluación," Instituto Nacional de Evaluación Educativa.

Keane, M. P. and K. I. Wolpin (1997): "The Career Decisions of Young Men," Journal of Political Economy, 105, 473-522.

LAVY, V. (2011): "What Makes an Effective Teacher? Quasi-Experimental Evidence," NBER Working Paper No. 16885.

Lazear, E. P. (2003): "Teacher Incentives," Swedish Economic Policy Review, 10, 179-241.

Murnane, R. J., J. B. Willet, And F. Levy (1995): "The Growing Importance of Cognitive Skills in Wage Determination," Review of Economics and Statistics, 77, 251-266.

Rivkin, S. G., E. A. Hanushek, And J. F. Kain (2005): "Teachers, Schools, and Academic Achievement," Econometrica, 73, 417-458.

Rockoff, J. E. (2004): "The Impact of Individual Teachers on Student Achievement: Evidence from Panel Data," American Economic Review Papers and Proceedings, 94, 247-252.

Schwerdt, G. And A. C. Wuppermann (2011): "Is traditional teaching really all that bad? A within-student between-subject approach," Economics of Education Review, 30, 365-379.

Van Klaveren, C. (2011): "Lecturing Style Teaching and Student Performance," Economics of Education Review, 30, 729-739.

Zemelman, S., H. Daniels, And A. Hyde (2005): Best Practice. Today's Standards for Teaching and Learning in America's Schools, Heinemann, third ed. 


\section{Figures}

Figure 1: Histogram of distribution of within-class gap between teacher and student indexes
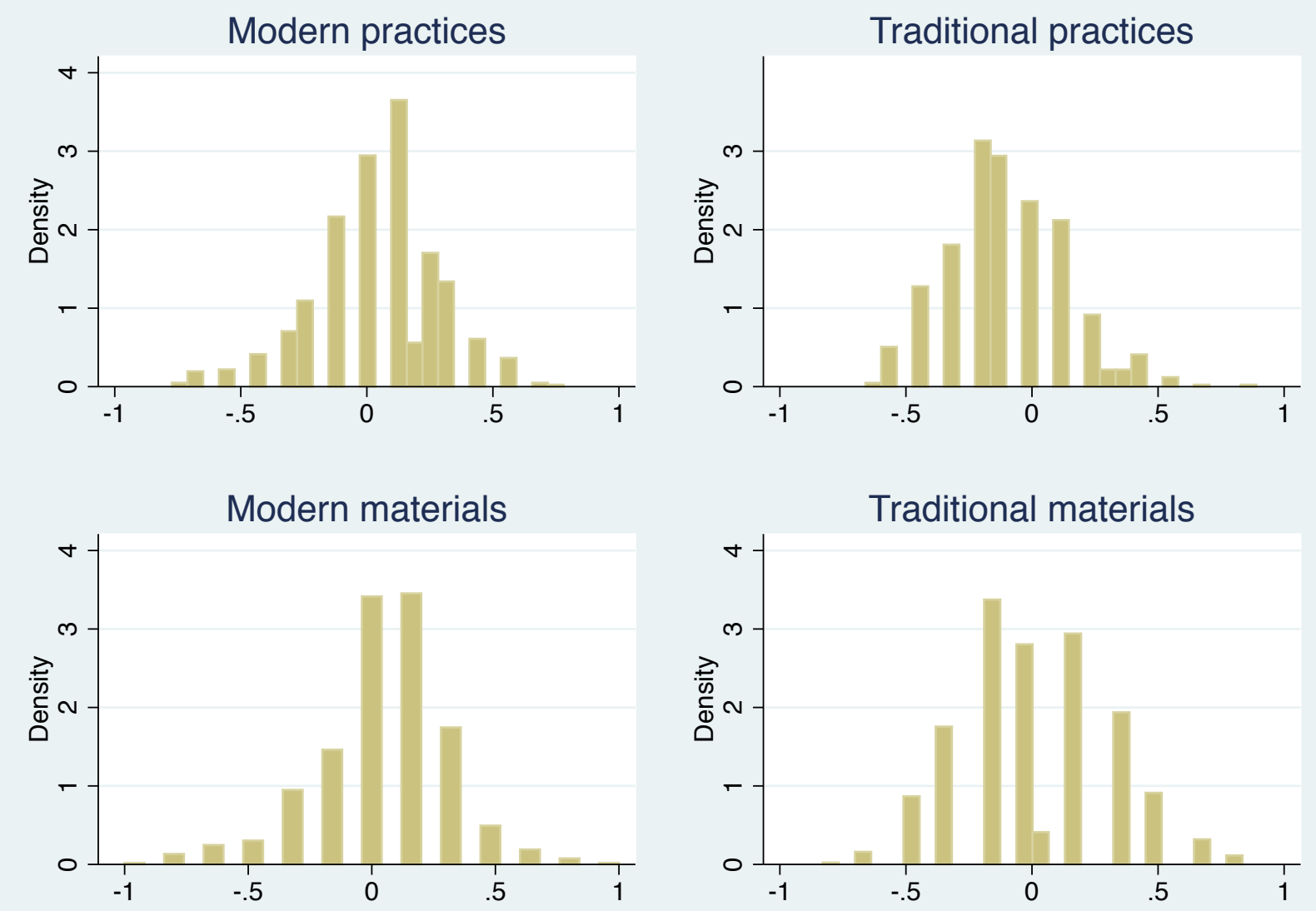


\section{Tables}

Table 1: Descriptive statistics of teacher

\begin{tabular}{|c|c|c|c|}
\hline & Mean & Std. Dev. & Classrooms \\
\hline Female & 0.75 & 0.43 & 716 \\
\hline \multicolumn{4}{|l|}{ Experience (years): } \\
\hline Less than 5 & 0.10 & 0.30 & 716 \\
\hline $5-9$ & 0.10 & 0.30 & 716 \\
\hline $10-14$ & 0.07 & 0.25 & 716 \\
\hline $15-19$ & 0.09 & 0.29 & 716 \\
\hline $20-24$ & 0.10 & 0.30 & 716 \\
\hline $25-29$ & 0.15 & 0.36 & 716 \\
\hline 30 or more & 0.39 & 0.49 & 716 \\
\hline 5 -years degree or more & 0.17 & 0.37 & 716 \\
\hline Class size & 16.44 & 4.61 & 716 \\
\hline \multicolumn{4}{|l|}{ Taught subjects: } \\
\hline Reading and Maths & 0.88 & 0.33 & 716 \\
\hline Reading & 0.05 & 0.22 & 716 \\
\hline Maths & 0.07 & 0.26 & 716 \\
\hline \multicolumn{4}{|l|}{ Training: } \\
\hline Attending courses & 0.95 & 0.21 & 538 \\
\hline Working teams at school & 0.93 & 0.26 & 480 \\
\hline Congresses and teaching projects & 0.88 & 0.33 & 386 \\
\hline \multicolumn{4}{|l|}{ Type of warnings to students: } \\
\hline Letter to the family & 0.68 & 0.46 & 679 \\
\hline Temporary class suspension & 0.16 & 0.37 & 663 \\
\hline \multicolumn{4}{|l|}{ Person asking for a meeting: } \\
\hline Parents & 0.22 & 0.41 & 714 \\
\hline Teacher & 0.33 & 0.47 & 714 \\
\hline Number of meetings with students' parents & 3.04 & 0.97 & 711 \\
\hline Teacher at $3^{r d}$ and $4^{\text {th }}$ grades & 0.74 & 0.44 & 709 \\
\hline Number of schools & & & 358 \\
\hline
\end{tabular}


Table 2: Descriptive statistics of students

\begin{tabular}{|c|c|c|c|}
\hline & Mean & Std. Dev. & Observations \\
\hline Female & 0.49 & 0.50 & 11774 \\
\hline Repeater & 0.05 & 0.23 & 11774 \\
\hline Born in 4 th quarter & 0.32 & 0.47 & 11774 \\
\hline Living in single-parent household & 0.07 & 0.26 & 11774 \\
\hline Living with siblings & 0.85 & 0.36 & 11774 \\
\hline \multicolumn{4}{|l|}{ Country of origin: } \\
\hline Spain & 0.93 & 0.26 & 11774 \\
\hline Western Europe & 0.00 & 0.05 & 11774 \\
\hline Non-Western Europe & 0.02 & 0.12 & 11774 \\
\hline Morocco & 0.00 & 0.07 & 11774 \\
\hline Latin America & 0.05 & 0.21 & 11774 \\
\hline Asia & 0.00 & 0.04 & 11774 \\
\hline Other & 0.00 & 0.06 & 11774 \\
\hline \multicolumn{4}{|l|}{ Age at starting school: } \\
\hline 2 years old or less & 0.60 & 0.49 & 11774 \\
\hline 3 years old & 0.36 & 0.48 & 11774 \\
\hline 4 years old & 0.03 & 0.16 & 11774 \\
\hline 5 years old & 0.01 & 0.10 & 11774 \\
\hline 6 years old & 0.00 & 0.07 & 11774 \\
\hline \multicolumn{4}{|l|}{ Mother's education: } \\
\hline Primary or less & 0.10 & 0.30 & 11774 \\
\hline Compulsory & 0.24 & 0.43 & 11774 \\
\hline High School & 0.14 & 0.35 & 11774 \\
\hline Vocational training & 0.20 & 0.40 & 11774 \\
\hline University & 0.31 & 0.46 & 11774 \\
\hline \multicolumn{4}{|l|}{ Father's education: } \\
\hline Primary or less & 0.13 & 0.33 & 11774 \\
\hline Compulsory & 0.26 & 0.44 & 11774 \\
\hline High School & 0.15 & 0.36 & 11774 \\
\hline Vocational training & 0.20 & 0.40 & 11774 \\
\hline University & 0.26 & 0.44 & 11774 \\
\hline \multicolumn{4}{|l|}{ Mother's labor status: } \\
\hline Self-employed & 0.13 & 0.34 & 11774 \\
\hline Employee & 0.52 & 0.50 & 11774 \\
\hline Unemployed & 0.10 & 0.30 & 11774 \\
\hline Inactive & 0.25 & 0.43 & 11774 \\
\hline \multicolumn{4}{|l|}{ Father's labor status: } \\
\hline Self-employed & 0.26 & 0.44 & 11774 \\
\hline Employee & 0.65 & 0.48 & 11774 \\
\hline Unemployed & 0.07 & 0.26 & 11774 \\
\hline Inactive & 0.02 & 0.13 & 11774 \\
\hline \multicolumn{4}{|l|}{ Help with homework: } \\
\hline Private tutor & 0.09 & 0.29 & 11602 \\
\hline Family & 0.61 & 0.49 & 11602 \\
\hline Number of schools & & & 358 \\
\hline
\end{tabular}


Table 3: Descriptive statistics of test scores

\begin{tabular}{lcc}
\hline \hline & Maths & Reading \\
\hline Full sample & 0.13 & 0.14 \\
& $(1.00)$ & $(0.98)$ \\
By gender: & & \\
Male & 0.21 & 0.09 \\
& $(1.03)$ & $(0.97)$ \\
Female & 0.06 & 0.19 \\
& $(0.96)$ & $(0.98)$ \\
Gap (male-female) & 0.15 & -0.05
\end{tabular}

By type of school:

$\begin{array}{lcc}\text { Public } & 0.04 & 0.04 \\ & (1.00) & (0.99) \\ \text { Private } & 0.30 & 0.31 \\ & (0.98) & (0.93) \\ \text { Gap (public-private) } & -0.26 & -0.27 \\ & & \\ \text { Students } & 11774 & 11774 \\ \text { Classrooms } & 716 & 716 \\ \text { Schools } & 358 & 358\end{array}$

Test scores are standardised with mean 0 and standard devia-

tion 1. Standard deviation in parenthesis

Table 4: Matched teacher questionnaire items

\begin{tabular}{c|c}
\hline \hline Traditional Teaching Practices & Modern Teaching Practices \\
\hline Item (a): Most of the time I teach by telling & $\begin{array}{c}\text { Item (b): Students present works or topics } \\
\text { to classmates }\end{array}$ \\
$\begin{array}{c}\text { Item (f): Students work on exercises and activities } \\
\text { proposed by me }\end{array}$ & Item (e): I promote discussions \\
Item (g): Students work individually & Item (h): Students work in small groups \\
\hline Traditional Teaching Materials & Modern Teaching Materials \\
\hline Item (a): Textbook & Item (f): Computers and internet \\
Item (b): Workbook & Item (g): Audiovisual aids \\
\hline
\end{tabular}

Teachers respond to the question "How often do you use the following teaching practices/materials in your lessons this school year?". Possible answers are "Never or almost never", "Sometimes", "Almost always", and "Always". 
Table 5: Correlation across teaching practices (Tutor's answers)

\begin{tabular}{|c|c|c|c|c|c|c|c|c|c|}
\hline & & \multicolumn{4}{|c|}{ Modern items } & \multicolumn{4}{|c|}{ Traditional items } \\
\hline & & (b) & (e) & (h) & (d) & (a) & $(\mathrm{f})$ & (g) & (c) \\
\hline \multirow{5}{*}{$\begin{array}{l}\text { Modern } \\
\text { items }\end{array}$} & (b) & 1.00 & & & & & & & \\
\hline & (e) & $0.25^{* *}$ & 1.00 & & & & & & \\
\hline & & $10.00)$ & & & & & & & \\
\hline & (h) & $\begin{array}{l}0.26^{* *} \\
(0.00)\end{array}$ & $\begin{array}{c}0.26^{* *} \\
(0.00)\end{array}$ & 1.00 & & & & & \\
\hline & (d) & $\begin{array}{c}0.07 \\
(0.08)\end{array}$ & $\begin{array}{l}0.18^{* *} \\
(0.00)\end{array}$ & $\begin{array}{l}0.12^{* *} \\
(0.00)\end{array}$ & 1.00 & & & & \\
\hline \multirow{4}{*}{$\begin{array}{l}\text { Traditional } \\
\text { items }\end{array}$} & (a) & $\begin{array}{c}0.09^{* *} \\
(0.01)\end{array}$ & $\begin{array}{l}-0.03 \\
(0.37)\end{array}$ & $\begin{array}{l}-0.02 \\
(0.65)\end{array}$ & $\begin{array}{c}0.10^{* *} \\
(0.01)\end{array}$ & 1.00 & & & \\
\hline & (f) & $\begin{array}{c}0.07 \\
(0.06)\end{array}$ & $\begin{array}{l}0.09^{* *} \\
(0.02)\end{array}$ & $\begin{array}{c}0.06 \\
(0.12)\end{array}$ & $\begin{array}{l}0.26^{* *} \\
(0.00)\end{array}$ & $\begin{array}{l}0.13^{* *} \\
(0.00)\end{array}$ & 1.00 & & \\
\hline & (g) & $\begin{array}{l}-0.05 \\
(0.22)\end{array}$ & $\begin{array}{c}-0.10^{* *} \\
(0.01)\end{array}$ & $\begin{array}{c}-0.13^{* *} \\
(0.00)\end{array}$ & $\begin{array}{c}0.09^{* *} \\
(0.02)\end{array}$ & $\begin{array}{c}0.25^{* *} \\
(0.00)\end{array}$ & $\begin{array}{c}0.30^{* *} \\
(0.00)\end{array}$ & 1.00 & \\
\hline & (c) & $\begin{array}{l}0.11^{* *} \\
(0.00)\end{array}$ & $\begin{array}{l}0.19^{* *} \\
(0.00)\end{array}$ & $\begin{array}{c}0.07 \\
(0.05)\end{array}$ & $\begin{array}{c}0.46^{* *} \\
(0.00)\end{array}$ & $\begin{array}{l}0.20^{* *} \\
(0.00)\end{array}$ & $\begin{array}{l}0.14^{* *} \\
(0.00)\end{array}$ & $\begin{array}{l}0.09^{* *} \\
(0.02)\end{array}$ & 1.00 \\
\hline
\end{tabular}

Sample: 358 schools, 716 classrooms, 11774 students. Standard deviation in parenthesis. ${ }^{* *} p<0.05 .(\mathrm{b}):$ "Students present works or topics to classmates"; (e): "I promote discussions"; (h): "Students work in small groups"; (d): "While I teach, students ask me doubts"; (a): "Most of the time I teach by telling"; (f): "Students work on exercises and activities proposed by me"; (g): "Students work individually"; (c): "While I teach, I ask students questions about the lesson".

Table 6: Descriptive statistics of indexes

\begin{tabular}{lccccc}
\hline \hline & Mean & Std. Dev. & Min. & Max. & Classrooms \\
\hline Tutor's answers: & & & & & \\
$\quad$ Modern practices & 0.43 & 0.14 & 0.00 & 0.89 & 716 \\
Traditional practices & 0.66 & 0.15 & 0.11 & 1.00 & 716 \\
Modern materials & 0.34 & 0.16 & 0.00 & 1.00 & 716 \\
$\quad$ Traditional materials & 0.65 & 0.20 & 0.00 & 1.00 & 716 \\
Students' answers: & & & & & \\
$\quad$ Modern practices & 0.40 & 0.10 & 0.13 & 1.00 & 716 \\
Traditional practices & 0.76 & 0.08 & 0.37 & 0.95 & 716 \\
Modern materials & 0.32 & 0.10 & 0.00 & 0.81 & 716 \\
Traditional materials & 0.65 & 0.08 & 0.33 & 0.87 & 716 \\
\hline \hline
\end{tabular}


Table 7: Correlations

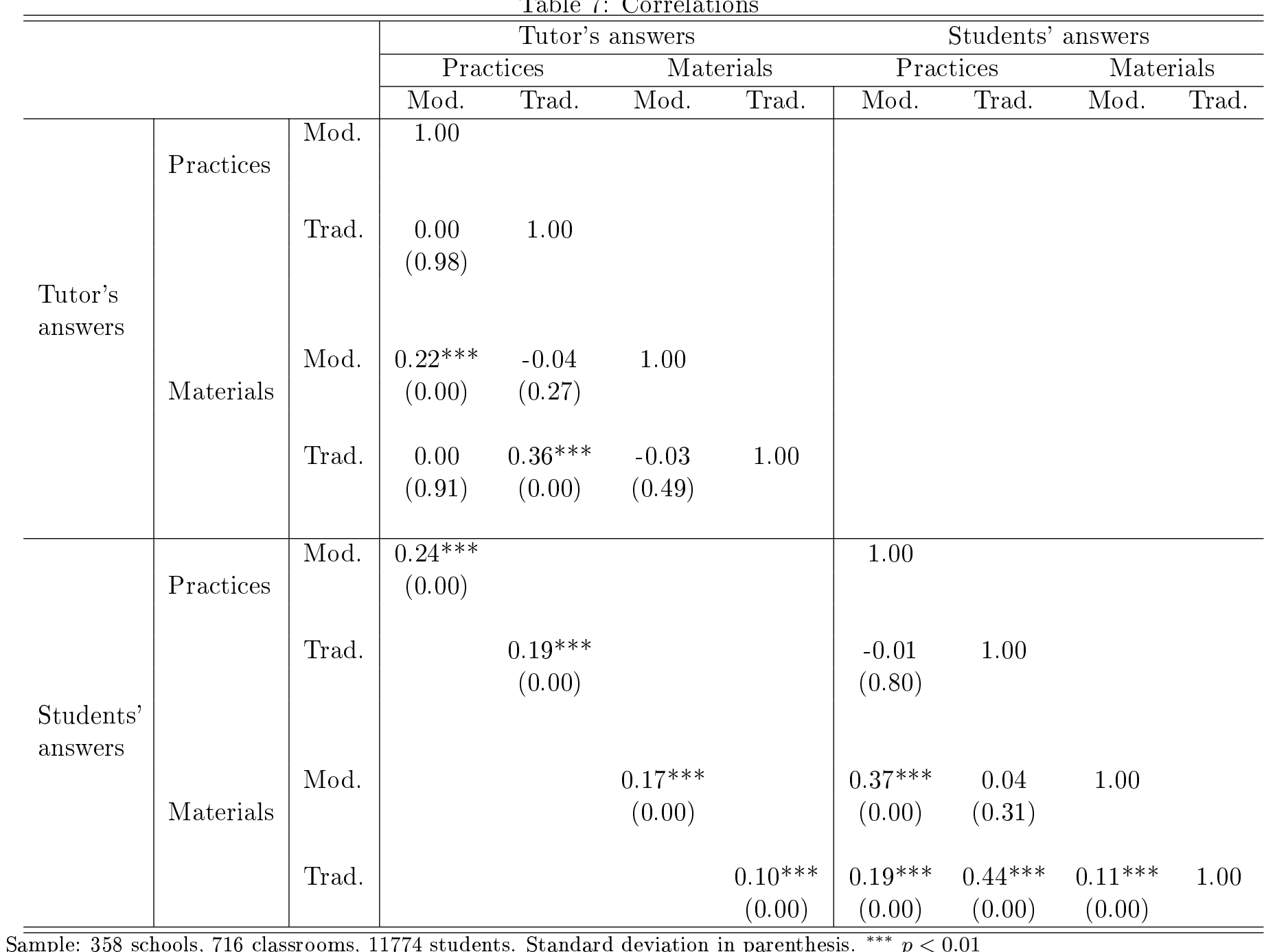


Table 8: Distribution of within-class gap between teacher and student indexes

\begin{tabular}{lccccc}
\hline \hline & Mean & Std. Dev. & Min. & Max. & Classrooms \\
\hline Modern practices & 0.03 & 0.15 & -0.53 & 0.55 & 661 \\
Traditional practices & -0.10 & 0.15 & -0.58 & 0.52 & 669 \\
Modern materials & 0.03 & 0.17 & -0.59 & 0.73 & 659 \\
Traditional materials & 0.01 & 0.21 & -0.84 & 0.56 & 685 \\
\hline
\end{tabular}

Table 9: Decomposition of variance in class-level means

\begin{tabular}{lrrrr}
\hline \hline & \multicolumn{4}{c}{ Tutor's answers } \\
\cline { 2 - 5 } & \multicolumn{3}{c}{ Teaching } & \multicolumn{2}{c}{ Materials } \\
\cline { 2 - 5 } Overall & 0.18 & 0.21 & 0.23 & 0.38 \\
\cline { 2 - 5 } Between & 0.13 & 0.14 & 0.18 & 0.30 \\
Within & 0.06 & 0.07 & 0.05 & 0.08 \\
\% within & 30.61 & 33.59 & 23.31 & 21.16 \\
& \multicolumn{5}{c}{} \\
& \multicolumn{5}{c}{ Students' } \\
\cline { 2 - 5 } & \multicolumn{5}{c}{ Teaching } \\
\cline { 2 - 5 } Overall & Modern & Traditional & Modern & Traditional \\
\cline { 2 - 5 } Between & 0.09 & 0.06 & 0.09 & 0.05 \\
Within & 0.06 & 0.04 & 0.06 & 0.03 \\
\% within & 0.03 & 0.02 & 0.03 & 0.02 \\
\hline \hline
\end{tabular}

Sample: 358 schools, 716 classrooms, 11774 students 
Table 10: Within-school assignment of teachers to classrooms: effect of class-level characteristics

\begin{tabular}{|c|c|c|c|c|c|c|c|c|c|c|c|c|c|}
\hline & \multicolumn{13}{|c|}{ Dependent variable: Teacher characteristic } \\
\hline & \multirow[b]{2}{*}{ Female } & \multicolumn{6}{|c|}{ Years of experience } & \multirow{2}{*}{$\begin{array}{l}5 \text {-years } \\
\text { degree }\end{array}$} & \multicolumn{2}{|c|}{ Taught subjects } & \multirow{2}{*}{$\begin{array}{l}\text { Teacher } \\
3^{r d}-4^{t h} \text { g. }\end{array}$} & \multicolumn{2}{|c|}{ Teach. Practices } \\
\hline & & $5-9$ & $10-14$ & $15-19$ & $20-24$ & $25-29$ & $\geq 30$ & & Read-Maths & Read & & Trad. & Mod. \\
\hline \multicolumn{14}{|l|}{ Mother educ.: } \\
\hline \multirow[t]{2}{*}{ Compulsory } & 0.17 & 0.21 & 0.16 & 0.01 & -0.20 & $-0.42^{*}$ & 0.30 & 0.18 & -0.23 & 0.06 & 0.25 & -0.08 & -0.05 \\
\hline & $(0.27)$ & $(0.21)$ & $(0.18)$ & $(0.23)$ & $(0.19)$ & $(0.23)$ & $(0.37)$ & $(0.21)$ & $(0.23)$ & $(0.21)$ & $(0.25)$ & $(0.10)$ & $(0.09)$ \\
\hline \multirow[t]{2}{*}{ High School } & 0.27 & -0.07 & $0.45^{* *}$ & -0.10 & -0.06 & -0.34 & 0.19 & 0.31 & -0.10 & 0.03 & 0.04 & -0.08 & -0.04 \\
\hline & $(0.35)$ & $(0.26)$ & $(0.18)$ & $(0.25)$ & $(0.28)$ & $(0.31)$ & $(0.44)$ & $(0.30)$ & $(0.24)$ & $(0.22)$ & $(0.32)$ & $(0.12)$ & $(0.10)$ \\
\hline \multirow[t]{2}{*}{ Vocational } & -0.04 & 0.08 & 0.29 & -0.06 & -0.26 & -0.16 & 0.24 & 0.01 & -0.14 & -0.02 & -0.07 & $-0.23^{*}$ & 0.01 \\
\hline & $(0.34)$ & $(0.24)$ & $(0.20)$ & $(0.23)$ & $(0.29)$ & $(0.31)$ & $(0.46)$ & $(0.30)$ & $(0.26)$ & $(0.22)$ & $(0.35)$ & $(0.13)$ & $(0.10)$ \\
\hline \multirow[t]{2}{*}{ University } & 0.07 & 0.04 & $0.34^{*}$ & 0.02 & -0.35 & -0.43 & 0.28 & 0.19 & -0.17 & -0.00 & -0.36 & -0.01 & -0.10 \\
\hline & $(0.36)$ & $(0.22)$ & $(0.19)$ & $(0.23)$ & $(0.27)$ & $(0.29)$ & $(0.45)$ & $(0.32)$ & $(0.25)$ & $(0.23)$ & $(0.34)$ & $(0.12)$ & $(0.10)$ \\
\hline \multicolumn{14}{|l|}{ Father educ.: } \\
\hline \multirow[t]{2}{*}{ Compulsory } & -0.29 & -0.09 & 0.03 & -0.06 & $0.49^{*}$ & 0.33 & -0.36 & -0.19 & $0.57^{* * *}$ & $-0.34^{*}$ & 0.20 & 0.06 & 0.04 \\
\hline & $(0.35)$ & $(0.21)$ & $(0.20)$ & $(0.25)$ & $(0.25)$ & $(0.26)$ & $(0.43)$ & $(0.26)$ & $(0.20)$ & $(0.19)$ & $(0.32)$ & $(0.11)$ & $(0.10)$ \\
\hline \multirow[t]{2}{*}{ High School } & $-0.61^{*}$ & -0.04 & $-0.43^{* *}$ & 0.15 & $0.56^{*}$ & $0.56^{*}$ & -0.30 & -0.44 & 0.04 & 0.04 & 0.40 & 0.15 & -0.07 \\
\hline & $(0.36)$ & $(0.23)$ & $(0.19)$ & $(0.21)$ & $(0.29)$ & $(0.29)$ & $(0.42)$ & $(0.32)$ & $(0.19)$ & $(0.21)$ & $(0.30)$ & $(0.11)$ & $(0.10)$ \\
\hline \multirow[t]{2}{*}{ Vocational } & -0.35 & -0.03 & -0.19 & 0.16 & 0.39 & $0.62^{* *}$ & $-0.77^{*}$ & $-0.57^{*}$ & 0.23 & -0.17 & -0.04 & 0.11 & 0.01 \\
\hline & $(0.35)$ & $(0.22)$ & $(0.19)$ & $(0.23)$ & $(0.29)$ & $(0.31)$ & $(0.42)$ & $(0.30)$ & $(0.23)$ & $(0.21)$ & $(0.34)$ & $(0.10)$ & $(0.09)$ \\
\hline \multirow[t]{2}{*}{ University } & -0.13 & 0.15 & -0.12 & -0.19 & $0.65^{* *}$ & 0.40 & -0.67 & -0.28 & 0.13 & -0.18 & 0.19 & -0.01 & 0.02 \\
\hline & $(0.36)$ & $(0.22)$ & $(0.19)$ & $(0.24)$ & $(0.29)$ & $(0.32)$ & $(0.43)$ & $(0.32)$ & $(0.20)$ & $(0.20)$ & $(0.32)$ & $(0.11)$ & $(0.10)$ \\
\hline \multicolumn{14}{|l|}{$\%$ non-Spanish } \\
\hline \multirow[t]{2}{*}{$10-20 \%$} & -0.02 & 0.05 & 0.02 & -0.08 & $-0.07^{*}$ & -0.02 & 0.04 & $0.13^{* *}$ & -0.02 & 0.00 & 0.01 & 0.01 & -0.01 \\
\hline & $(0.07)$ & $(0.05)$ & $(0.03)$ & $(0.05)$ & $(0.04)$ & $(0.07)$ & $(0.08)$ & $(0.05)$ & $(0.03)$ & $(0.02)$ & $(0.06)$ & $(0.02)$ & $(0.02)$ \\
\hline \multirow[t]{2}{*}{ More $20 \%$} & -0.11 & 0.05 & $0.11^{*}$ & -0.03 & -0.07 & -0.01 & -0.11 & $0.24^{* *}$ & -0.04 & 0.05 & -0.07 & -0.01 & 0.03 \\
\hline & $(0.10)$ & $(0.08)$ & $(0.06)$ & $(0.06)$ & $(0.08)$ & $(0.08)$ & $(0.12)$ & $(0.10)$ & $(0.07)$ & $(0.05)$ & $(0.10)$ & $(0.03)$ & $(0.03)$ \\
\hline \multirow[t]{2}{*}{$\%$ siblings } & -0.19 & 0.19 & 0.05 & -0.07 & -0.09 & -0.11 & 0.19 & -0.07 & 0.11 & -0.18 & $0.37^{*}$ & 0.11 & -0.01 \\
\hline & $(0.21)$ & $(0.17)$ & $(0.12)$ & $(0.12)$ & $(0.18)$ & $(0.19)$ & $(0.23)$ & $(0.24)$ & $(0.16)$ & $(0.11)$ & $(0.22)$ & $(0.07)$ & $(0.06)$ \\
\hline
\end{tabular}

Each column is a separate regression, including school fixed effects. Reference outcomes: primary education, $<10 \%$ non-Spanish, self-employed.

Standard errors clustered at the school level in parentheses. ${ }^{*} p<0.10,{ }^{* *} p<0.05,{ }^{* * *} p<0.01$. (Continued on next page) 
Table 10: (continued)

Dependent variable: Teacher characteristic

\begin{tabular}{|c|c|c|c|c|c|c|c|c|c|c|c|c|c|}
\hline & \multicolumn{13}{|c|}{ Dependent variable: Teacher characteristic } \\
\hline & \multirow[b]{2}{*}{ Female } & \multicolumn{6}{|c|}{ Years of experience } & \multirow{2}{*}{$\begin{array}{l}\text { 5-years } \\
\text { degree }\end{array}$} & \multicolumn{2}{|c|}{ Taught subjects } & \multirow{2}{*}{$\begin{array}{l}\text { Teacher } \\
3^{r d}-4^{t h} \text { g. }\end{array}$} & \multicolumn{2}{|c|}{ Teach. Practices } \\
\hline & & $5-9$ & $10-14$ & $15-19$ & $20-24$ & $25-29$ & $\geq 30$ & & Read-Maths & Read & & Trad. & Mod. \\
\hline \multirow[t]{2}{*}{ \% single-hh } & 0.04 & 0.02 & 0.11 & 0.03 & -0.26 & -0.19 & 0.41 & -0.19 & 0.11 & 0.01 & 0.28 & -0.02 & $-0.17^{*}$ \\
\hline & $(0.31)$ & $(0.21)$ & $(0.19)$ & $(0.21)$ & $(0.28)$ & $(0.29)$ & $(0.41)$ & $(0.33)$ & $(0.20)$ & $(0.16)$ & $(0.31)$ & $(0.10)$ & $(0.10)$ \\
\hline \multirow[t]{2}{*}{$\%$ female } & $-0.33^{*}$ & 0.14 & 0.03 & -0.01 & -0.09 & 0.06 & -0.01 & 0.05 & -0.10 & -0.07 & 0.22 & -0.01 & 0.06 \\
\hline & $(0.20)$ & $(0.13)$ & $(0.12)$ & $(0.14)$ & $(0.15)$ & $(0.18)$ & $(0.25)$ & $(0.18)$ & $(0.13)$ & $(0.13)$ & $(0.18)$ & $(0.06)$ & $(0.06)$ \\
\hline \multirow[t]{2}{*}{$\%$ repeater } & 0.17 & $0.42^{*}$ & 0.00 & -0.27 & -0.01 & 0.10 & -0.13 & 0.28 & $0.56^{* * *}$ & -0.29 & 0.05 & 0.12 & 0.04 \\
\hline & $(0.41)$ & $(0.23)$ & $(0.28)$ & $(0.25)$ & $(0.30)$ & $(0.33)$ & $(0.44)$ & $(0.32)$ & $(0.22)$ & $(0.19)$ & $(0.38)$ & $(0.11)$ & $(0.10)$ \\
\hline \multicolumn{14}{|c|}{ Mother employm.: } \\
\hline \multirow[t]{2}{*}{ Employee } & $0.57^{* *}$ & -0.07 & -0.07 & 0.02 & -0.06 & 0.34 & -0.39 & 0.05 & -0.17 & 0.07 & -0.10 & 0.02 & 0.04 \\
\hline & $(0.25)$ & $(0.18)$ & $(0.18)$ & $(0.20)$ & $(0.17)$ & $(0.22)$ & $(0.29)$ & $(0.25)$ & $(0.14)$ & $(0.12)$ & $(0.22)$ & $(0.08)$ & $(0.08)$ \\
\hline \multirow[t]{2}{*}{ Unemployed } & 0.23 & -0.11 & 0.12 & -0.21 & -0.09 & 0.02 & 0.24 & 0.10 & $-0.50^{* *}$ & $0.32^{* *}$ & -0.22 & 0.09 & -0.08 \\
\hline & $(0.31)$ & $(0.26)$ & $(0.24)$ & $(0.25)$ & $(0.23)$ & $(0.28)$ & $(0.40)$ & $(0.34)$ & $(0.21)$ & $(0.16)$ & $(0.29)$ & $(0.11)$ & $(0.09)$ \\
\hline \multirow[t]{2}{*}{ Inactive } & 0.36 & -0.01 & -0.04 & -0.00 & -0.19 & $0.60^{* *}$ & -0.49 & -0.04 & -0.11 & 0.06 & -0.12 & 0.05 & 0.00 \\
\hline & $(0.28)$ & $(0.19)$ & $(0.19)$ & $(0.23)$ & $(0.21)$ & $(0.26)$ & $(0.36)$ & $(0.27)$ & $(0.17)$ & $(0.15)$ & $(0.27)$ & $(0.10)$ & $(0.09)$ \\
\hline \multicolumn{14}{|c|}{ Father employm.: } \\
\hline \multirow[t]{2}{*}{ Employee } & 0.01 & 0.14 & 0.01 & 0.19 & $-0.29^{*}$ & -0.04 & -0.02 & -0.23 & 0.21 & -0.02 & 0.11 & 0.04 & $-0.14^{* * *}$ \\
\hline & $(0.22)$ & $(0.13)$ & $(0.10)$ & $(0.16)$ & $(0.16)$ & $(0.18)$ & $(0.25)$ & $(0.21)$ & $(0.15)$ & $(0.10)$ & $(0.18)$ & $(0.06)$ & $(0.05)$ \\
\hline \multirow[t]{2}{*}{ Unemployed } & -0.50 & 0.12 & 0.13 & $0.49^{*}$ & 0.11 & -0.06 & $-0.83^{*}$ & $-0.63^{*}$ & 0.01 & -0.02 & -0.17 & -0.07 & $-0.24^{* * *}$ \\
\hline & $(0.35)$ & $(0.29)$ & $(0.24)$ & $(0.26)$ & $(0.27)$ & $(0.30)$ & $(0.43)$ & $(0.35)$ & $(0.20)$ & $(0.12)$ & $(0.35)$ & $(0.11)$ & $(0.09)$ \\
\hline \multirow[t]{2}{*}{ Inactive } & -0.85 & -0.54 & 0.31 & -0.05 & -0.73 & 1.00 & 0.10 & 0.29 & 0.60 & $-0.68^{* *}$ & 0.43 & 0.07 & -0.18 \\
\hline & $(0.67)$ & $(0.38)$ & $(0.39)$ & $(0.37)$ & $(0.51)$ & $(0.61)$ & $(0.84)$ & $(0.51)$ & $(0.38)$ & $(0.30)$ & $(0.59)$ & $(0.19)$ & $(0.15)$ \\
\hline Observations & 11774 & 11774 & 11774 & 11774 & 11774 & 11774 & 11774 & 11774 & 11774 & 11774 & 11664 & 11774 & 11774 \\
\hline$R^{2}$ & 0.59 & 0.58 & 0.58 & 0.61 & 0.53 & 0.57 & 0.56 & 0.55 & 0.73 & 0.59 & 0.65 & 0.68 & 0.71 \\
\hline F-test & 1.22 & 0.88 & 0.92 & 0.70 & 1.17 & 1.22 & 0.94 & 1.15 & 1.36 & 0.86 & 0.92 & 0.89 & 1.44 \\
\hline $\mathrm{p}$-value & 0.24 & 0.61 & 0.56 & 0.82 & 0.28 & 0.24 & 0.53 & 0.30 & 0.14 & 0.64 & 0.56 & 0.60 & 0.10 \\
\hline
\end{tabular}

Each column is a separate regression, including school fixed effects. Reference outcomes: primary education, $<10 \%$ non-Spanish, self-employed.

${ }^{*} p<0.10,{ }^{* *} p<0.05,{ }^{* * *} p<0.01$. Standard errors clustered at the school level in parentheses. F-test: joint significance of class-level variables. 
Table 11: Within-school assignment of teachers to classrooms: effect of teaching practices

\begin{tabular}{|c|c|c|c|c|c|}
\hline & \multicolumn{5}{|c|}{ Dependent variable: Student characteristic } \\
\hline \multirow{3}{*}{ Traditional teaching } & Single-parent hh & Siblings & Female & Repeater & Non-Spanish \\
\hline & -0.01 & 0.07 & 0.00 & 0.03 & -0.01 \\
\hline & $(0.03)$ & $(0.04)$ & $(0.05)$ & $(0.02)$ & $(0.03)$ \\
\hline \multirow[t]{2}{*}{ Modern teaching } & -0.05 & 0.02 & 0.07 & -0.00 & -0.00 \\
\hline & $(0.03)$ & $(0.04)$ & $(0.06)$ & $(0.03)$ & $(0.03)$ \\
\hline F-test & 1.51 & 1.34 & 0.78 & 0.80 & 0.22 \\
\hline p-value & 0.22 & 0.26 & 0.46 & 0.45 & 0.80 \\
\hline$R^{2}$ & 0.04 & 0.06 & 0.05 & 0.06 & 0.13 \\
\hline Observations & 11774 & 11774 & 11774 & 11774 & 11774 \\
\hline \multirow{4}{*}{ Traditional teaching } & \multicolumn{4}{|c|}{ Mother's education } & \\
\hline & Compulsory & High School & Vocational training & University & \\
\hline & -0.02 & 0.01 & $-0.08^{*}$ & 0.05 & \\
\hline & $(0.05)$ & $(0.04)$ & $(0.04)$ & $(0.05)$ & \\
\hline \multirow[t]{2}{*}{ Modern teaching } & -0.00 & -0.01 & 0.04 & -0.04 & \\
\hline & $(0.05)$ & $(0.04)$ & $(0.05)$ & $(0.05)$ & \\
\hline F-test & 0.09 & 0.07 & 2.07 & 1.09 & \\
\hline p-value & 0.91 & 0.93 & 0.13 & 0.34 & \\
\hline$R^{2}$ & 0.11 & 0.05 & 0.06 & 0.21 & \\
\hline \multirow[t]{3}{*}{ Observations } & 11774 & 11774 & 11774 & 11774 & \\
\hline & \multicolumn{4}{|c|}{ Father's education } & \\
\hline & Compulsory & High School & Vocational training & University & \\
\hline \multirow[t]{2}{*}{ Traditional teaching } & -0.02 & 0.05 & 0.03 & -0.03 & \\
\hline & $(0.04)$ & $(0.04)$ & $(0.04)$ & $(0.05)$ & \\
\hline \multirow[t]{2}{*}{ Modern teaching } & 0.02 & -0.04 & 0.00 & 0.01 & \\
\hline & $(0.05)$ & $(0.04)$ & $(0.05)$ & $(0.05)$ & \\
\hline F-test & 0.15 & 1.09 & 0.23 & 0.29 & \\
\hline p-value & 0.86 & 0.34 & 0.79 & 0.75 & \\
\hline$R^{2}$ & 0.10 & 0.04 & 0.06 & 0.22 & \\
\hline Observations & 11774 & 11774 & 11774 & 11774 & \\
\hline \multirow{4}{*}{ Traditional teaching } & \multicolumn{3}{|c|}{ Mother's labor status } & & \\
\hline & Employee & Unemployed & Inactive & & \\
\hline & -0.00 & 0.03 & -0.00 & & \\
\hline & $(0.06)$ & $(0.03)$ & $(0.05)$ & & \\
\hline \multirow[t]{2}{*}{ Modern teaching } & 0.02 & -0.06 & 0.03 & & \\
\hline & $(0.06)$ & $(0.04)$ & $(0.05)$ & & \\
\hline F-test & 0.04 & 1.58 & 0.17 & & \\
\hline p-value & 0.96 & 0.21 & 0.85 & & \\
\hline$R^{2}$ & 0.10 & 0.06 & 0.09 & & \\
\hline \multirow[t]{3}{*}{ Observations } & 11774 & 11774 & 11774 & & \\
\hline & \multicolumn{3}{|c|}{ Father's labor status } & & \\
\hline & Employee & Unemployed & Inactive & & \\
\hline \multirow[t]{2}{*}{ Traditional teaching } & 0.04 & -0.01 & 0.01 & & \\
\hline & $(0.05)$ & $(0.03)$ & $(0.01)$ & & \\
\hline \multirow[t]{2}{*}{ Modern teaching } & -0.07 & $-0.06^{* *}$ & -0.01 & & \\
\hline & $(0.05)$ & $(0.03)$ & $(0.01)$ & & \\
\hline F-test & 1.10 & 2.29 & 0.20 & & \\
\hline p-value & 0.33 & 0.10 & 0.82 & & \\
\hline$R^{2}$ & 0.05 & 0.08 & 0.04 & & \\
\hline Observations & 11774 & 11774 & 11774 & & \\
\hline
\end{tabular}

Each column in each panel is a separate regression, including school fixed effects. Traditional and modern teaching reported by tutor. Standard errors clustered at the school level in parentheses. ${ }^{*} p<0.10,{ }^{* *} p<0.05,{ }^{* * *} p<0.01$. F-test: joint significance of traditional and modern teaching indexes. 
Table 12: Within-school assignment of teachers to classrooms: effect of class size

\begin{tabular}{lcc|cc}
\hline \hline \multirow{2}{*}{ Class size } & \multicolumn{2}{l|}{ Traditional teaching practices } & \multicolumn{2}{c}{ Modern teaching practices } \\
\cline { 2 - 5 } & -0.00 & -0.01 & -0.02 & 0.00 \\
& $(0.01)$ & $(0.02)$ & $(0.02)$ & $(0.02)$ \\
Class size $^{2}$ & 0.00 & 0.00 & 0.00 & -0.00 \\
& $(0.00)$ & $(0.00)$ & $(0.00)$ & $(0.00)$ \\
\hline F-test & 0.03 & 0.35 & 0.93 & 0.42 \\
p-value & 0.97 & 0.71 & 0.40 & 0.66 \\
School fixed effects & No & Yes & No & Yes \\
$R^{2}$ & 0.00 & 0.67 & 0.00 & 0.70 \\
Observations & 11774 & 11774 & 11774 & 11774 \\
\hline \hline
\end{tabular}

Traditional and modern teaching reported by tutor. Standard errors clustered at the school level in parentheses. ${ }^{*} p<0.10,{ }^{* *} p<0.05,{ }^{* * *} p<0.01$. F-test: joint significance of class size and class size $^{2}$. 
Table 13: Within-school assignment of teachers to classrooms: Effect of teacher characteristics

\begin{tabular}{|c|c|c|}
\hline & \multicolumn{2}{|c|}{ Dependent variable: Teaching index } \\
\hline & Traditional & Modern \\
\hline \multirow[t]{2}{*}{ Female } & -0.02 & 0.02 \\
\hline & $(0.02)$ & $(0.02)$ \\
\hline \multicolumn{3}{|l|}{ Years of experience $($ ref: $<5)$ : } \\
\hline \multirow{2}{*}{$5-9$} & 0.03 & 0.01 \\
\hline & $(0.03)$ & $(0.03)$ \\
\hline \multirow[t]{2}{*}{$10-14$} & 0.04 & 0.02 \\
\hline & $(0.03)$ & $(0.03)$ \\
\hline \multirow[t]{2}{*}{$15-19$} & 0.02 & 0.03 \\
\hline & $(0.03)$ & $(0.04)$ \\
\hline \multirow[t]{2}{*}{$20-24$} & 0.02 & 0.01 \\
\hline & $(0.03)$ & $(0.03)$ \\
\hline \multirow[t]{2}{*}{$25-29$} & 0.00 & 0.02 \\
\hline & $(0.03)$ & $(0.03)$ \\
\hline \multirow[t]{2}{*}{30 or more } & 0.03 & 0.02 \\
\hline & $(0.03)$ & $(0.03)$ \\
\hline \multirow[t]{2}{*}{5 -years degree or more } & $-0.04^{*}$ & -0.00 \\
\hline & $(0.02)$ & $(0.02)$ \\
\hline \multicolumn{3}{|l|}{ Taught subjects (ref: Maths): } \\
\hline \multirow[t]{2}{*}{ Reading and Maths } & -0.00 & -0.01 \\
\hline & $(0.04)$ & $(0.03)$ \\
\hline \multirow[t]{2}{*}{ Reading } & 0.01 & 0.01 \\
\hline & $(0.06)$ & $(0.05)$ \\
\hline \multicolumn{3}{|l|}{ Person asking for a meeting: } \\
\hline \multirow[t]{2}{*}{ Parents } & 0.01 & -0.02 \\
\hline & $(0.03)$ & $(0.02)$ \\
\hline \multirow[t]{2}{*}{ Teacher } & -0.01 & -0.01 \\
\hline & $(0.02)$ & $(0.02)$ \\
\hline \multirow[t]{2}{*}{ \# of meetings with parents } & 0.02 & -0.00 \\
\hline & $(0.02)$ & $(0.02)$ \\
\hline \multirow[t]{2}{*}{ Teacher at $3^{r d}$ and $4^{\text {th }}$ grades } & -0.00 & -0.01 \\
\hline & $(0.02)$ & $(0.02)$ \\
\hline \multirow[t]{2}{*}{ Class size } & -0.00 & -0.00 \\
\hline & $(0.00)$ & $(0.00)$ \\
\hline \multirow[t]{2}{*}{ Constant } & $0.45^{* * *}$ & $0.57^{* * *}$ \\
\hline & $(0.09)$ & $(0.08)$ \\
\hline F-test & 0.79 & 0.20 \\
\hline p-value & 0.68 & 1.00 \\
\hline School fixed effects & Yes & Yes \\
\hline$R^{2}$ & 0.69 & 0.70 \\
\hline Observations & 11583 & 11583 \\
\hline
\end{tabular}

Traditional and modern teaching reported by tutor. Standard errors clustered at the school level in parentheses. ${ }^{*} p<0.10,{ }^{* *} p<0.05,{ }^{* * *} p<0.01$. F-test: joint significance of teacher characteristics. 
Table 14: Estimation results (Teaching practices)

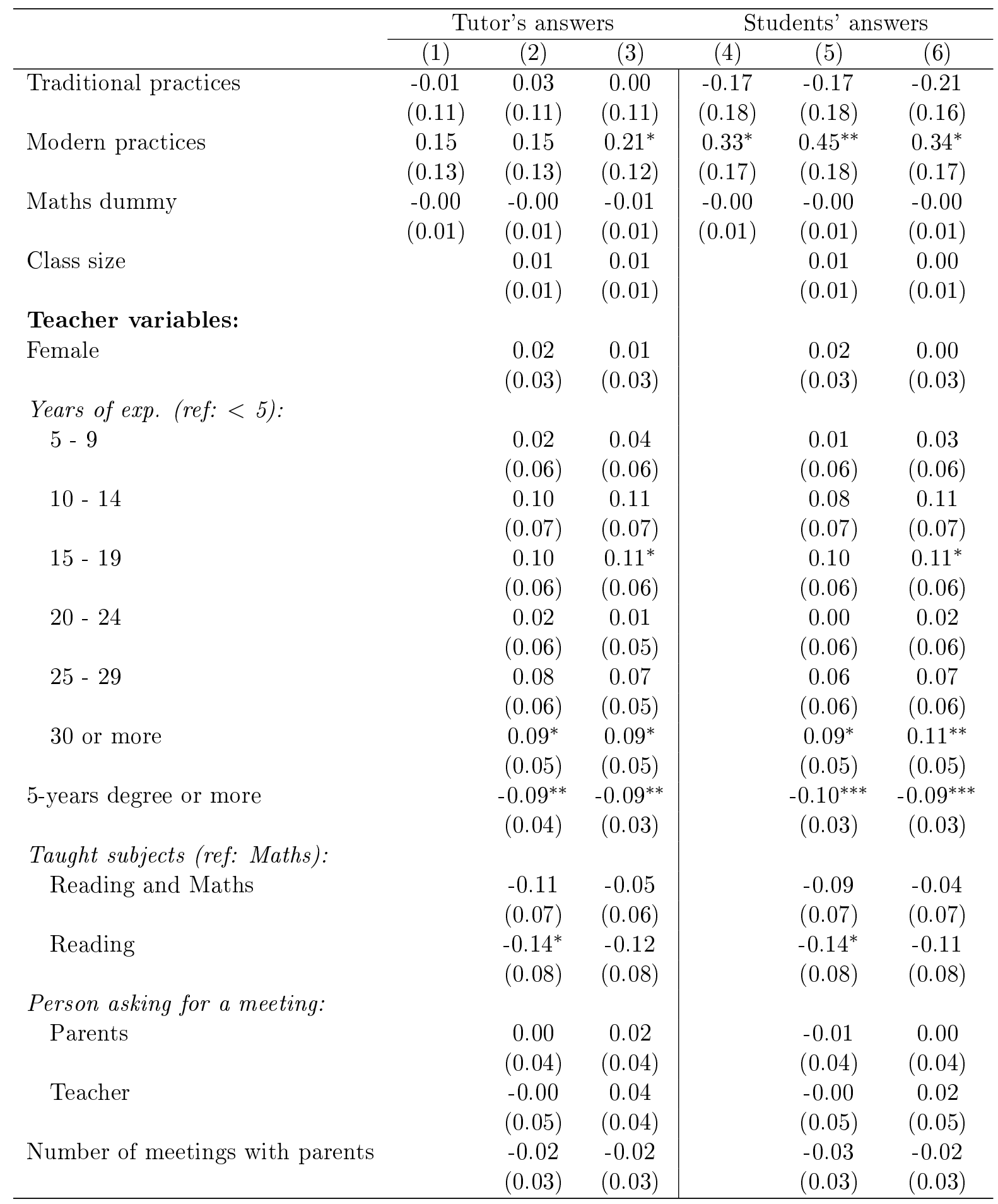

Dependent variable: Student test score in maths and reading. Standard errors clustered at school level in parentheses. ${ }^{*} p<0.10,{ }^{* *} p<0.05,{ }^{* * *} p<0.01$. (Continued on next page) 
Table 14: (continued)

\begin{tabular}{lccc|ccc}
\hline & \multicolumn{3}{c}{ Tutor's answers } & \multicolumn{3}{c}{ Students' answers } \\
\cline { 2 - 7 } & $(1)$ & $(2)$ & $(3)$ & $(4)$ & $(5)$ & $(6)$ \\
\hline Teacher at $3^{\text {rd }}$ and $4^{\text {th }}$ grades & & 0.03 & $0.06^{*}$ & & 0.03 & 0.04 \\
Constant & & $(0.03)$ & $(0.03)$ & & $(0.04)$ & $(0.04)$ \\
& $0.81^{* * *}$ & $0.69^{* * *}$ & 0.37 & $0.95^{* * *}$ & $0.92^{* * *}$ & $0.73^{* * *}$ \\
& $(0.09)$ & $(0.25)$ & $(0.25)$ & $(0.13)$ & $(0.27)$ & $(0.27)$ \\
\hline Student's characteristics & No & No & Yes & No & No & Yes \\
School FE & Yes & Yes & Yes & Yes & Yes & Yes \\
Observations & 23548 & 23166 & 22826 & 21452 & 21100 & 20900 \\
$R^{2}$ & 0.15 & 0.15 & 0.22 & 0.14 & 0.14 & 0.21 \\
\hline
\end{tabular}

Dependent variable: Student test score in maths and reading. Standard errors clustered at school level in parentheses. ${ }^{*} p<0.10,{ }^{* *} p<0.05,{ }^{* * *} p<0.01$. Student's characteristics: female, country of origin, repeater, mother and father's education, mother and father's labor status, single-parent household, siblings, born in $4^{\text {th }}$ quarter, age at starting school, private tutor/family helps with homework. 
Table 15: Estimation results (Teaching materials)

\begin{tabular}{|c|c|c|c|c|c|c|}
\hline & \multicolumn{3}{|c|}{ Tutor's answers } & \multicolumn{3}{|c|}{ Students' answers } \\
\hline & (1) & $(2)$ & $(3)$ & (4) & (5) & $(6)$ \\
\hline \multirow[t]{2}{*}{ Traditional materials } & 0.13 & 0.10 & 0.13 & 0.00 & -0.03 & -0.15 \\
\hline & $(0.11)$ & $(0.11)$ & $(0.11)$ & $(0.16)$ & $(0.16)$ & $(0.16)$ \\
\hline \multirow[t]{2}{*}{ Modern materials } & 0.07 & 0.04 & 0.03 & 0.15 & 0.23 & 0.21 \\
\hline & $(0.11)$ & $(0.11)$ & $(0.11)$ & $(0.18)$ & $(0.18)$ & $(0.17)$ \\
\hline \multirow[t]{2}{*}{ Maths dummy } & -0.00 & -0.00 & -0.01 & -0.01 & -0.01 & -0.01 \\
\hline & $(0.01)$ & $(0.01)$ & $(0.01)$ & $(0.01)$ & $(0.01)$ & $(0.01)$ \\
\hline \multirow[t]{2}{*}{ Class size } & & 0.01 & 0.01 & & 0.01 & 0.01 \\
\hline & & $(0.01)$ & $(0.01)$ & & $(0.01)$ & $(0.01)$ \\
\hline \multicolumn{7}{|l|}{ Teacher variables: } \\
\hline \multirow[t]{2}{*}{ Female } & & 0.02 & 0.01 & & 0.03 & 0.02 \\
\hline & & $(0.03)$ & $(0.03)$ & & $(0.03)$ & $(0.03)$ \\
\hline \multicolumn{7}{|l|}{ Years of exp. $($ ref: $<5)$ : } \\
\hline \multirow[t]{2}{*}{$5-9$} & & 0.02 & 0.04 & & 0.04 & 0.04 \\
\hline & & $(0.06)$ & $(0.05)$ & & $(0.06)$ & $(0.06)$ \\
\hline \multirow[t]{2}{*}{$10-14$} & & 0.10 & 0.10 & & 0.10 & 0.11 \\
\hline & & $(0.07)$ & $(0.07)$ & & $(0.07)$ & $(0.07)$ \\
\hline \multirow[t]{2}{*}{$15-19$} & & 0.10 & $0.11^{*}$ & & $0.11^{*}$ & $0.12^{* *}$ \\
\hline & & $(0.06)$ & $(0.06)$ & & $(0.06)$ & $(0.06)$ \\
\hline \multirow[t]{2}{*}{$20-24$} & & 0.02 & 0.02 & & 0.00 & 0.01 \\
\hline & & $(0.06)$ & $(0.05)$ & & $(0.06)$ & $(0.05)$ \\
\hline \multirow[t]{2}{*}{$25-29$} & & 0.09 & 0.08 & & 0.08 & 0.08 \\
\hline & & $(0.06)$ & $(0.05)$ & & $(0.06)$ & $(0.05)$ \\
\hline \multirow[t]{2}{*}{30 or more } & & $0.09^{*}$ & $0.09^{*}$ & & 0.07 & $0.08^{*}$ \\
\hline & & $(0.05)$ & $(0.04)$ & & $(0.05)$ & $(0.04)$ \\
\hline \multirow[t]{2}{*}{5 -years degree or more } & & $-0.09^{* *}$ & $-0.08^{* *}$ & & $-0.11^{* * *}$ & $-0.09^{* * *}$ \\
\hline & & $(0.04)$ & $(0.03)$ & & $(0.04)$ & $(0.03)$ \\
\hline \multicolumn{7}{|l|}{ Taught subjects (ref: Maths): } \\
\hline \multirow[t]{2}{*}{ Reading and Maths } & & -0.11 & -0.05 & & -0.09 & -0.04 \\
\hline & & $(0.07)$ & $(0.06)$ & & $(0.06)$ & $(0.06)$ \\
\hline \multirow[t]{2}{*}{ Reading } & & $-0.14^{*}$ & -0.12 & & $-0.14^{*}$ & -0.12 \\
\hline & & $(0.07)$ & $(0.08)$ & & $(0.07)$ & $(0.08)$ \\
\hline \multicolumn{7}{|l|}{ Person asking for a meeting: } \\
\hline \multirow[t]{2}{*}{ Parents } & & -0.00 & 0.01 & & 0.01 & 0.02 \\
\hline & & $(0.04)$ & $(0.04)$ & & $(0.04)$ & $(0.04)$ \\
\hline \multirow[t]{2}{*}{ Teacher } & & -0.00 & 0.04 & & 0.00 & 0.04 \\
\hline & & $(0.05)$ & $(0.04)$ & & $(0.05)$ & $(0.05)$ \\
\hline \multirow[t]{2}{*}{ Number of meetings with parents } & & -0.03 & -0.02 & & -0.01 & -0.01 \\
\hline & & $(0.03)$ & $(0.03)$ & & $(0.03)$ & $(0.03)$ \\
\hline
\end{tabular}

Dependent variable: Student test score in maths and reading. Standard errors clustered at school level in parentheses. ${ }^{*} p<0.10,{ }^{* *} p<0.05,{ }^{* * *} p<0.01$. (Continued on next page) 
Table 15: (continued)

\begin{tabular}{lccc|ccc}
\hline & \multicolumn{3}{c}{ Tutor's answers } & \multicolumn{3}{c}{ Students' answers } \\
\cline { 2 - 7 } & $(1)$ & $(2)$ & $(3)$ & $(4)$ & $(5)$ & $(6)$ \\
\hline Teacher at $3^{\text {rd }}$ and $4^{\text {th }}$ grades & & 0.03 & $0.06^{*}$ & & 0.04 & 0.05 \\
Constant & & $(0.03)$ & $(0.03)$ & & $(0.03)$ & $(0.03)$ \\
& $0.77^{* * *}$ & $0.70^{* * *}$ & 0.40 & $0.83^{* * *}$ & $0.57^{* *}$ & $0.49^{*}$ \\
& $(0.09)$ & $(0.25)$ & $(0.25)$ & $(0.10)$ & $(0.26)$ & $(0.26)$ \\
\hline Student's characteristics & No & No & Yes & No & No & Yes \\
School FE & Yes & Yes & Yes & Yes & Yes & Yes \\
Observations & 23548 & 23166 & 22826 & 21926 & 21578 & 21360 \\
$R^{2}$ & 0.15 & 0.15 & 0.22 & 0.14 & 0.14 & 0.21 \\
\hline
\end{tabular}

Dependent variable: Student test score in maths and reading. Standard errors clustered at school level in parentheses. ${ }^{*} p<0.10,{ }^{* *} p<0.05,{ }^{* * *} p<0.01$. Student's characteristics: female, country of origin, repeater, mother and father's education, mother and father's labor status, single-parent household, siblings, born in $4^{\text {th }}$ quarter, age at starting school, private tutor/family helps with homework. 
Table 16: Estimation results (Maths)

\begin{tabular}{|c|c|c|c|c|}
\hline & $\begin{array}{c}\text { Tutor } \\
(1)\end{array}$ & $\begin{array}{c}\text { Students } \\
(2)\end{array}$ & $\begin{array}{c}\text { Tutor } \\
(3)\end{array}$ & $\begin{array}{c}\text { Students } \\
(4)\end{array}$ \\
\hline Traditional practices & $\begin{array}{c}0.03 \\
(0.13)\end{array}$ & $\begin{array}{l}-0.11 \\
(0.21)\end{array}$ & & \\
\hline Modern practices & $\begin{array}{c}0.11 \\
(0.15)\end{array}$ & $\begin{array}{c}0.25 \\
(0.20)\end{array}$ & & \\
\hline Traditional materials & & & $\begin{array}{c}0.10 \\
(0.13)\end{array}$ & $\begin{array}{l}-0.10 \\
(0.20)\end{array}$ \\
\hline Modern materials & & & $\begin{array}{l}-0.08 \\
(0.13)\end{array}$ & $\begin{array}{l}-0.06 \\
(0.22)\end{array}$ \\
\hline Class size & $\begin{array}{c}0.01 \\
(0.01)\end{array}$ & $\begin{array}{c}0.00 \\
(0.01)\end{array}$ & $\begin{array}{c}0.01 \\
(0.01)\end{array}$ & $\begin{array}{c}0.01 \\
(0.01)\end{array}$ \\
\hline \multicolumn{5}{|l|}{ Teacher variables: } \\
\hline Female & $\begin{array}{l}-0.01 \\
(0.03)\end{array}$ & $\begin{array}{l}-0.00 \\
(0.04)\end{array}$ & $\begin{array}{l}-0.01 \\
(0.04)\end{array}$ & $\begin{array}{c}0.00 \\
(0.04)\end{array}$ \\
\hline \multicolumn{5}{|l|}{ Years of exp. $($ ref: $<5)$ : } \\
\hline $5-9$ & $\begin{array}{l}-0.01 \\
(0.07)\end{array}$ & $\begin{array}{l}-0.02 \\
(0.07)\end{array}$ & $\begin{array}{l}-0.01 \\
(0.06)\end{array}$ & $\begin{array}{l}-0.01 \\
(0.06)\end{array}$ \\
\hline $10-14$ & $\begin{array}{c}0.06 \\
(0.08)\end{array}$ & $\begin{array}{c}0.09 \\
(0.09)\end{array}$ & $\begin{array}{c}0.06 \\
(0.08)\end{array}$ & $\begin{array}{c}0.08 \\
(0.09)\end{array}$ \\
\hline $15-19$ & $\begin{array}{l}0.14^{*} \\
(0.07)\end{array}$ & $\begin{array}{c}0.13^{*} \\
(0.08)\end{array}$ & $\begin{array}{l}0.14^{*} \\
(0.07)\end{array}$ & $\begin{array}{l}0.15^{* *} \\
(0.07)\end{array}$ \\
\hline $20-24$ & $\begin{array}{c}0.05 \\
(0.07)\end{array}$ & $\begin{array}{c}0.05 \\
(0.07)\end{array}$ & $\begin{array}{c}0.05 \\
(0.07)\end{array}$ & $\begin{array}{c}0.05 \\
(0.07)\end{array}$ \\
\hline $25-29$ & $\begin{array}{c}0.08 \\
(0.06)\end{array}$ & $\begin{array}{c}0.07 \\
(0.07)\end{array}$ & $\begin{array}{c}0.09 \\
(0.06)\end{array}$ & $\begin{array}{c}0.09 \\
(0.06)\end{array}$ \\
\hline 30 or more & $\begin{array}{c}0.08 \\
(0.06)\end{array}$ & $\begin{array}{c}0.10^{*} \\
(0.06)\end{array}$ & $\begin{array}{c}0.09 \\
(0.06)\end{array}$ & $\begin{array}{c}0.08 \\
(0.06)\end{array}$ \\
\hline 5 -years degree or more & $\begin{array}{c}-0.08^{* *} \\
(0.04)\end{array}$ & $\begin{array}{c}-0.09^{* *} \\
(0.04)\end{array}$ & $\begin{array}{c}-0.07^{* *} \\
(0.04)\end{array}$ & $\begin{array}{c}-0.08^{* *} \\
(0.04)\end{array}$ \\
\hline \multicolumn{5}{|c|}{ Taught subjects (ref: Maths): } \\
\hline Reading and Maths & $\begin{array}{l}-0.06 \\
(0.08)\end{array}$ & $\begin{array}{l}-0.05 \\
(0.08)\end{array}$ & $\begin{array}{l}-0.06 \\
(0.07)\end{array}$ & $\begin{array}{l}-0.05 \\
(0.07)\end{array}$ \\
\hline Reading & $\begin{array}{l}-0.16 \\
(0.10)\end{array}$ & $\begin{array}{l}-0.17^{*} \\
(0.10)\end{array}$ & $\begin{array}{l}-0.16^{*} \\
(0.10)\end{array}$ & $\begin{array}{l}-0.16 \\
(0.10)\end{array}$ \\
\hline \multicolumn{5}{|c|}{ Person asking for a meeting: } \\
\hline Parents & $\begin{array}{c}0.04 \\
(0.05)\end{array}$ & $\begin{array}{c}0.02 \\
(0.05)\end{array}$ & $\begin{array}{c}0.04 \\
(0.05)\end{array}$ & $\begin{array}{c}0.04 \\
(0.05)\end{array}$ \\
\hline Teacher & $\begin{array}{c}0.03 \\
(0.05)\end{array}$ & $\begin{array}{c}0.02 \\
(0.05)\end{array}$ & $\begin{array}{c}0.02 \\
(0.05)\end{array}$ & $\begin{array}{c}0.03 \\
(0.05)\end{array}$ \\
\hline
\end{tabular}

Dependent variable: Student test score in maths. Standard errors clustered at school level in parentheses. ${ }^{*} p<0.10,{ }^{* *} p<0.05,{ }^{* * *} p<0.01$. (Continued on next page) 
Table 16: (continued)

\begin{tabular}{lcccc}
\hline & Tutor & Students & Tutor & Students \\
\cline { 2 - 5 } & $(1)$ & $(2)$ & $(3)$ & $(4)$ \\
\hline Number of meetings with students' parents & -0.02 & -0.02 & -0.02 & -0.01 \\
& $(0.03)$ & $(0.03)$ & $(0.03)$ & $(0.03)$ \\
Teacher at $3^{\text {rd }}$ and $4^{\text {th }}$ grades & $0.07^{*}$ & 0.06 & $0.07^{*}$ & 0.06 \\
& $(0.04)$ & $(0.04)$ & $(0.04)$ & $(0.04)$ \\
Constant & $0.52^{*}$ & $0.77^{* *}$ & $0.59^{*}$ & $0.69^{* *}$ \\
& $(0.31)$ & $(0.35)$ & $(0.32)$ & $(0.33)$ \\
\hline Student's characteristics & Yes & Yes & Yes & Yes \\
School FE & Yes & Yes & Yes & Yes \\
Observations & 11413 & 10450 & 11413 & 10680 \\
$R^{2}$ & 0.23 & 0.23 & 0.23 & 0.23 \\
\hline
\end{tabular}

Dependent variable: Student test score in maths. Standard errors clustered at school level in parentheses. ${ }^{*} p<0.10,{ }^{* *} p<0.05,{ }^{* * *} p<0.01$. Student's characteristics: female, country of origin, repeater, mother and father's education, mother and father's labor status, single-parent household, siblings, born in $4^{\text {th }}$ quarter, age at starting school, particular teacher or family helps with homework. 
Table 17: Estimation results (Reading)

\begin{tabular}{|c|c|c|c|c|}
\hline & $\begin{array}{c}\text { Tutor } \\
(1)\end{array}$ & $\begin{array}{c}\text { Students } \\
(2)\end{array}$ & $\begin{array}{c}\text { Tutor } \\
(3)\end{array}$ & $\begin{array}{c}\text { Students } \\
\text { (4) }\end{array}$ \\
\hline Traditional practices & $\begin{array}{l}-0.03 \\
(0.12)\end{array}$ & $\begin{array}{l}-0.32^{*} \\
(0.18)\end{array}$ & & \\
\hline Modern practices & $\begin{array}{l}0.31^{* *} \\
(0.13)\end{array}$ & $\begin{array}{l}0.43^{* *} \\
(0.21)\end{array}$ & & \\
\hline Traditional materials & & & $\begin{array}{c}0.16 \\
(0.11)\end{array}$ & $\begin{array}{l}-0.19 \\
(0.17)\end{array}$ \\
\hline Modern materials & & & $\begin{array}{c}0.13 \\
(0.12)\end{array}$ & $\begin{array}{l}0.48^{* *} \\
(0.19)\end{array}$ \\
\hline Class size & $\begin{array}{c}0.01 \\
(0.01)\end{array}$ & $\begin{array}{c}0.00 \\
(0.01)\end{array}$ & $\begin{array}{c}0.01 \\
(0.01)\end{array}$ & $\begin{array}{c}0.01 \\
(0.01)\end{array}$ \\
\hline \multicolumn{5}{|l|}{ Teacher variables: } \\
\hline Female & $\begin{array}{c}0.02 \\
(0.03)\end{array}$ & $\begin{array}{c}0.01 \\
(0.03)\end{array}$ & $\begin{array}{c}0.03 \\
(0.03)\end{array}$ & $\begin{array}{c}0.03 \\
(0.03)\end{array}$ \\
\hline \multicolumn{5}{|l|}{ Years of exp. $($ ref: $<5)$ : } \\
\hline $5-9$ & $\begin{array}{c}0.09 \\
(0.07)\end{array}$ & $\begin{array}{c}0.08 \\
(0.07)\end{array}$ & $\begin{array}{c}0.09 \\
(0.07)\end{array}$ & $\begin{array}{c}0.10 \\
(0.07)\end{array}$ \\
\hline $10-14$ & $\begin{array}{l}0.15^{* *} \\
(0.07)\end{array}$ & $\begin{array}{c}0.14^{*} \\
(0.08)\end{array}$ & $\begin{array}{l}0.15^{*} \\
(0.07)\end{array}$ & $\begin{array}{l}0.14^{*} \\
(0.08)\end{array}$ \\
\hline $15-19$ & $\begin{array}{c}0.07 \\
(0.07)\end{array}$ & $\begin{array}{c}0.09 \\
(0.07)\end{array}$ & $\begin{array}{c}0.08 \\
(0.07)\end{array}$ & $\begin{array}{c}0.10 \\
(0.07)\end{array}$ \\
\hline $20-24$ & $\begin{array}{l}-0.03 \\
(0.07)\end{array}$ & $\begin{array}{l}-0.02 \\
(0.07)\end{array}$ & $\begin{array}{l}-0.02 \\
(0.07)\end{array}$ & $\begin{array}{l}-0.03 \\
(0.07)\end{array}$ \\
\hline $25-29$ & $\begin{array}{c}0.06 \\
(0.06)\end{array}$ & $\begin{array}{c}0.06 \\
(0.07)\end{array}$ & $\begin{array}{c}0.07 \\
(0.07)\end{array}$ & $\begin{array}{c}0.07 \\
(0.07)\end{array}$ \\
\hline 30 or more & $\begin{array}{c}0.09 \\
(0.06)\end{array}$ & $\begin{array}{l}0.12^{* *} \\
(0.06)\end{array}$ & $\begin{array}{c}0.09 \\
(0.05)\end{array}$ & $\begin{array}{c}0.09 \\
(0.06)\end{array}$ \\
\hline 5 -years degree or more & $\begin{array}{c}-0.09^{* *} \\
(0.04)\end{array}$ & $\begin{array}{c}-0.09^{* *} \\
(0.04)\end{array}$ & $\begin{array}{c}-0.09^{* *} \\
(0.04)\end{array}$ & $\begin{array}{c}-0.11^{* *} \\
(0.04)\end{array}$ \\
\hline \multicolumn{5}{|c|}{ Taught subjects (ref: Maths): } \\
\hline Reading and Maths & $\begin{array}{l}-0.04 \\
(0.09)\end{array}$ & $\begin{array}{l}-0.02 \\
(0.09)\end{array}$ & $\begin{array}{l}-0.04 \\
(0.09)\end{array}$ & $\begin{array}{l}-0.04 \\
(0.09)\end{array}$ \\
\hline Reading & $\begin{array}{l}-0.09 \\
(0.10)\end{array}$ & $\begin{array}{l}-0.05 \\
(0.09)\end{array}$ & $\begin{array}{l}-0.09 \\
(0.09)\end{array}$ & $\begin{array}{l}-0.08 \\
(0.10)\end{array}$ \\
\hline \multicolumn{5}{|c|}{ Person asking for a meeting: } \\
\hline Parents & $\begin{array}{c}0.00 \\
(0.04)\end{array}$ & $\begin{array}{l}-0.01 \\
(0.05)\end{array}$ & $\begin{array}{l}-0.01 \\
(0.04)\end{array}$ & $\begin{array}{c}0.01 \\
(0.05)\end{array}$ \\
\hline Teacher & $\begin{array}{c}0.05 \\
(0.05)\end{array}$ & $\begin{array}{c}0.03 \\
(0.05)\end{array}$ & $\begin{array}{c}0.05 \\
(0.05)\end{array}$ & $\begin{array}{c}0.05 \\
(0.05)\end{array}$ \\
\hline
\end{tabular}

Dependent variable: Student test score in reading. Standard errors clustered at school level in parentheses. ${ }^{*} p<0.10,{ }^{* *} p<0.05,{ }^{* * *} p<0.01$. (Continued on next page) 
Table 17: (continued)

\begin{tabular}{lcccc}
\hline & Tutor & Students & Tutor & Students \\
\cline { 2 - 5 } & $(1)$ & $(2)$ & $(3)$ & $(4)$ \\
\hline Number of meetings with students' parents & -0.02 & -0.03 & -0.03 & -0.01 \\
& $(0.03)$ & $(0.03)$ & $(0.03)$ & $(0.03)$ \\
Teacher at $3^{\text {rd }}$ and $4^{\text {th }}$ grades & 0.05 & 0.03 & 0.04 & 0.04 \\
Constant & $(0.04)$ & $(0.04)$ & $(0.04)$ & $(0.04)$ \\
& 0.22 & $0.69^{* *}$ & 0.21 & 0.29 \\
\hline Student's characteristics & $(0.28)$ & $(0.30)$ & $(0.27)$ & $(0.29)$ \\
School FE & Yes & Yes & Yes & Yes \\
Observations & Yes & Yes & Yes & Yes \\
$R^{2}$ & 11413 & 10450 & 11413 & 10680 \\
\hline
\end{tabular}

Dependent variable: Student test score in reading. Standard errors clustered at school level in parentheses. ${ }^{*} p<0.10,{ }^{* *} p<0.05,{ }^{* * *} p<0.01$. Student's characteristics: female, country of origin, repeater, mother and father's education, mother and father's labor status, single-parent household, siblings, born in $4^{\text {th }}$ quarter, age at starting school, particular teacher or family helps with homework.

Table 18: Heterogeneous effects by gender

\begin{tabular}{|c|c|c|c|c|c|c|}
\hline & Both & ubjects & & ths & & ding \\
\hline & Boys & Girls & Boys & Girls & Boys & Girls \\
\hline A. Using tutor's ansu & & & & & & \\
\hline Traditional practices & 0.00 & -0.03 & 0.01 & -0.01 & -0.01 & -0.05 \\
\hline & $(0.14)$ & $(0.14)$ & $(0.17)$ & $(0.17)$ & $(0.16)$ & $(0.16)$ \\
\hline Modern practices & 0.22 & 0.22 & 0.12 & 0.12 & $0.33^{*}$ & $0.32^{*}$ \\
\hline & $(0.16)$ & $(0.16)$ & $(0.19)$ & $(0.20)$ & $(0.18)$ & $(0.17)$ \\
\hline Maths dummy & $0.12^{* * *}$ & $-0.13^{* * *}$ & - & - & - & - \\
\hline & $(0.02)$ & $(0.02)$ & - & - & - & - \\
\hline Observations & 11524 & 11302 & 5762 & 5651 & 5762 & 5651 \\
\hline B. Using students' an & & & & & & \\
\hline Traditional practices & 0.03 & $-0.49^{* *}$ & 0.05 & -0.31 & 0.01 & $-0.66^{* * *}$ \\
\hline & $(0.22)$ & $(0.23)$ & $(0.27)$ & $(0.29)$ & $(0.25)$ & $(0.24)$ \\
\hline Modern practices & 0.13 & $0.44^{*}$ & 0.12 & 0.24 & 0.14 & $0.65^{* *}$ \\
\hline & $(0.23)$ & $(0.23)$ & $(0.27)$ & $(0.28)$ & $(0.26)$ & $(0.27)$ \\
\hline Maths dummy & $0.12^{* * *}$ & $-0.13^{* * *}$ & - & - & - & - \\
\hline & $(0.02)$ & $(0.02)$ & - & - & - & - \\
\hline Observations & 10552 & 10348 & 5276 & 5174 & 5276 & 5174 \\
\hline
\end{tabular}

All regressions control for teacher and student characteristics, and school fixed effects. 
Table 19: Heterogeneous effects by type of school

\begin{tabular}{|c|c|c|c|c|c|c|}
\hline & Both & ubjects & & ths & $\operatorname{Re}$ & ling \\
\hline & Public & Private & Public & Private & Public & Private \\
\hline A. Using tutor's answ & & & & & & \\
\hline Traditional practices & -0.09 & 0.32 & -0.10 & $0.48^{*}$ & -0.08 & 0.16 \\
\hline & $(0.12)$ & $(0.23)$ & $(0.15)$ & $(0.26)$ & $(0.14)$ & $(0.24)$ \\
\hline Modern practices & 0.20 & 0.20 & 0.15 & 0.09 & 0.25 & 0.30 \\
\hline & $(0.17)$ & $(0.17)$ & $(0.21)$ & $(0.22)$ & $(0.18)$ & $(0.19)$ \\
\hline Maths dummy & -0.00 & -0.01 & - & - & - & - \\
\hline & $(0.02)$ & $(0.02)$ & - & - & - & - \\
\hline Observations & 14616 & 8210 & 7308 & 4105 & 7308 & 4105 \\
\hline B. Using students' an & & & & & & \\
\hline Traditional practices & $-0.34^{*}$ & 0.26 & -0.18 & 0.16 & $-0.50^{* *}$ & 0.35 \\
\hline & $(0.19)$ & $(0.32)$ & $(0.24)$ & $(0.39)$ & $(0.22)$ & $(0.32)$ \\
\hline Modern practices & $0.40^{* *}$ & 0.10 & 0.36 & -0.06 & $0.44^{*}$ & 0.26 \\
\hline & $(0.20)$ & $(0.35)$ & $(0.23)$ & $(0.42)$ & $(0.25)$ & $(0.34)$ \\
\hline Maths dummy & -0.00 & -0.01 & - & - & - & - \\
\hline & $(0.02)$ & $(0.02)$ & - & - & - & - \\
\hline Observations & 13226 & 7674 & 6613 & 3837 & 6613 & 3837 \\
\hline
\end{tabular}


Table 20: Robustness to include each index one at a time in the regression

\begin{tabular}{|c|c|c|c|c|c|c|c|c|c|c|c|c|}
\hline \multirow[b]{4}{*}{ A. Teaching practices } & \multicolumn{6}{|c|}{ Maths } & \multicolumn{6}{|c|}{ Reading } \\
\hline & \multicolumn{3}{|c|}{ Tutor's answers } & \multicolumn{3}{|c|}{ Students' answers } & \multicolumn{3}{|c|}{ Tutor's answers } & \multicolumn{3}{|c|}{ Students' answers } \\
\hline & (1) & $(2)$ & (3) & (4) & $(5)$ & $(6)$ & (7) & $(8)$ & (9) & $(10)$ & $(11)$ & $(12)$ \\
\hline & & & & & & & & & & & & \\
\hline Traditional index & $\begin{array}{c}0.03 \\
(0.13)\end{array}$ & $\begin{array}{c}0.04 \\
(0.13)\end{array}$ & & $\begin{array}{l}-0.11 \\
(0.21)\end{array}$ & $\begin{array}{l}-0.07 \\
(0.19)\end{array}$ & & $\begin{array}{c}-0.03 \\
(0.12)\end{array}$ & $\begin{array}{l}-0.01 \\
(0.12)\end{array}$ & & $\begin{array}{c}-0.32^{*} \\
(0.18)\end{array}$ & $\begin{array}{l}-0.21 \\
(0.17)\end{array}$ & \\
\hline Modern index & $\begin{array}{c}0.11 \\
(0.15)\end{array}$ & & $\begin{array}{c}0.11 \\
(0.15)\end{array}$ & $\begin{array}{c}0.25 \\
(0.20)\end{array}$ & & $\begin{array}{c}0.20 \\
(0.19)\end{array}$ & $\begin{array}{c}0.31^{* *} \\
(0.13)\end{array}$ & & $\begin{array}{c}0.31^{* *} \\
(0.13)\end{array}$ & $\begin{array}{l}0.43^{* *} \\
(0.21)\end{array}$ & & $\begin{array}{c}0.38^{*} \\
(0.20)\end{array}$ \\
\hline Observations & 11413 & 11413 & 11413 & 10450 & 10762 & 10691 & 11413 & 11413 & 11413 & 10450 & 10762 & 10691 \\
\hline B. Teaching materials & & & & & & & & & & & & \\
\hline Traditional index & $\begin{array}{c}0.10 \\
(0.13)\end{array}$ & $\begin{array}{c}0.10 \\
(0.13)\end{array}$ & & $\begin{array}{l}-0.10 \\
(0.20)\end{array}$ & $\begin{array}{l}-0.10 \\
(0.19)\end{array}$ & & $\begin{array}{c}0.16 \\
(0.11)\end{array}$ & $\begin{array}{c}0.16 \\
(0.11)\end{array}$ & & $\begin{array}{l}-0.19 \\
(0.17)\end{array}$ & $\begin{array}{l}-0.05 \\
(0.16)\end{array}$ & \\
\hline Modern index & $\begin{array}{l}-0.09 \\
(0.13)\end{array}$ & & $\begin{array}{l}-0.09 \\
(0.13)\end{array}$ & $\begin{array}{l}-0.06 \\
(0.22)\end{array}$ & & $\begin{array}{l}-0.08 \\
(0.21)\end{array}$ & $\begin{array}{c}0.13 \\
(0.12)\end{array}$ & & $\begin{array}{c}0.12 \\
(0.12)\end{array}$ & $\begin{array}{l}0.48^{* *} \\
(0.19)\end{array}$ & & $\begin{array}{c}0.42^{* *} \\
(0.18)\end{array}$ \\
\hline Observations & 11413 & 11413 & 11413 & 10680 & 11010 & 10742 & 11413 & 11413 & 11413 & 10680 & 11010 & 10742 \\
\hline
\end{tabular}


Table 21: Robustness to include items (c) and (d) in teaching practices measures

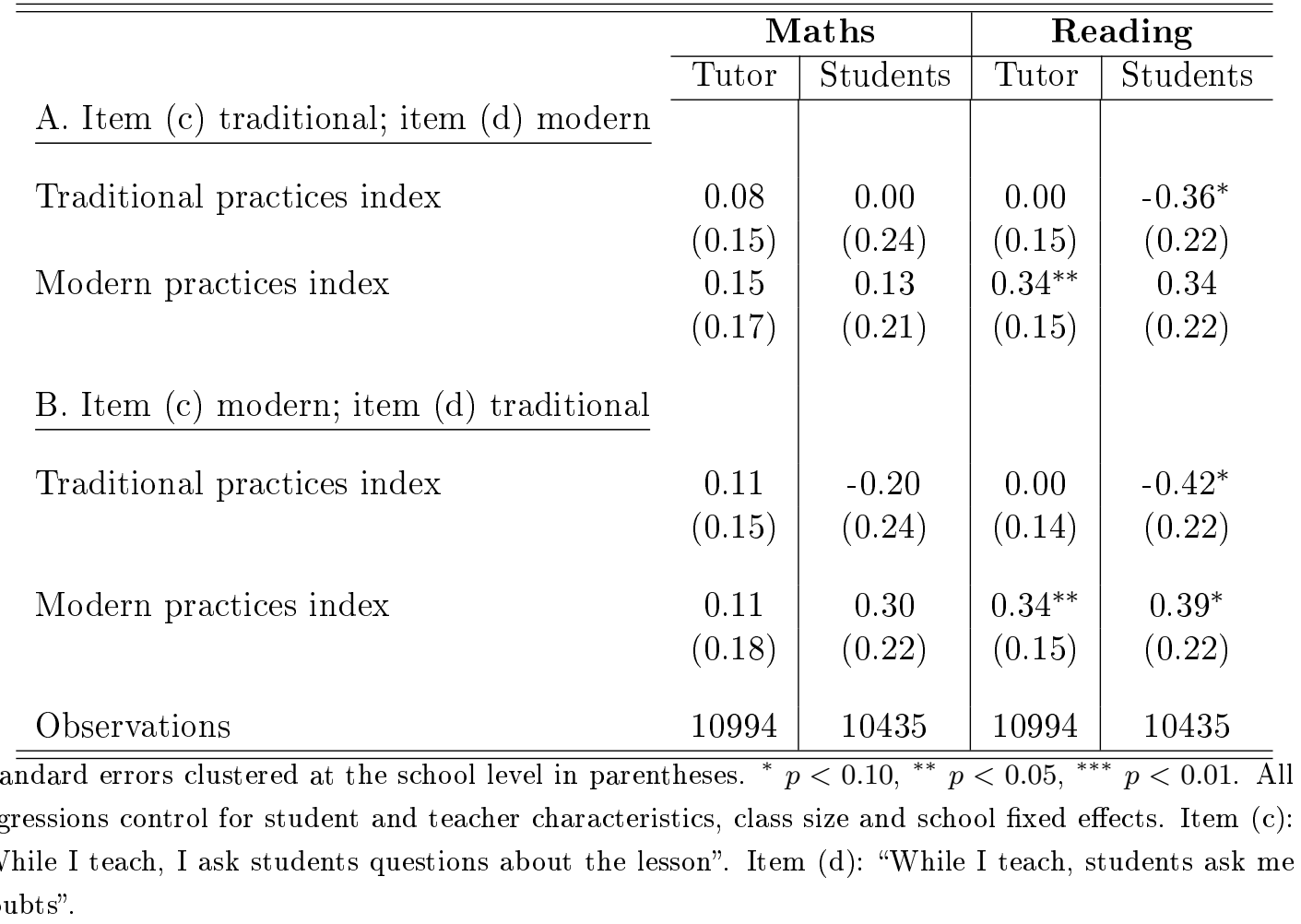

Table 22: Robustness to constraint total time allocated to items

\begin{tabular}{|c|c|c|c|c|c|c|c|c|}
\hline \multirow[b]{3}{*}{ Share of time using modern practices } & \multicolumn{4}{|c|}{ Maths } & \multicolumn{4}{|c|}{ Reading } \\
\hline & \multicolumn{2}{|c|}{ Tutor } & \multicolumn{2}{|c|}{ Students } & \multicolumn{2}{|c|}{ Tutor } & \multicolumn{2}{|c|}{ Students } \\
\hline & $\begin{array}{c}0.11 \\
(0.20)\end{array}$ & & $\begin{array}{c}0.23 \\
(0.28)\end{array}$ & & $\begin{array}{l}0.43^{* *} \\
(0.18)\end{array}$ & & $\begin{array}{c}0.56^{*} \\
(0.29)\end{array}$ & \\
\hline Share of time using modern materials & & $\begin{array}{c}-0.28 \\
(0.20)\end{array}$ & & $\begin{array}{l}-0.07 \\
(0.26)\end{array}$ & & $\begin{array}{c}-0.05 \\
(0.17)\end{array}$ & & $\begin{array}{c}0.41^{*} \\
(0.23)\end{array}$ \\
\hline Observations & 11413 & 11413 & 10443 & 10649 & 11413 & 11413 & 10443 & 10649 \\
\hline
\end{tabular}

Standard errors clustered at the school level in parentheses. ${ }^{*} p<0.10,{ }^{* *} p<0.05,{ }^{* * *} p<0.01$. All regressions control for student and teacher characteristics, class size and school fixed effects. Each cell represents a separate regression. 
Table 23: Robustness to include additional control variables

\begin{tabular}{|c|c|c|c|c|}
\hline \multirow[b]{3}{*}{ A. Class-average characteristics } & \multicolumn{2}{|c|}{ Maths } & \multicolumn{2}{|c|}{ Reading } \\
\hline & Tutor & Students & Tutor & Students \\
\hline & & & & \\
\hline Traditional practices index & $\begin{array}{c}0.03 \\
(0.13)\end{array}$ & $\begin{array}{l}-0.12 \\
(0.21)\end{array}$ & $\begin{array}{c}0.03 \\
(0.12)\end{array}$ & $\begin{array}{c}-0.29^{*} \\
(0.18)\end{array}$ \\
\hline Modern practices index & $\begin{array}{c}0.10 \\
(0.15)\end{array}$ & $\begin{array}{c}0.29 \\
(0.20)\end{array}$ & $\begin{array}{l}0.28^{* *} \\
(0.14)\end{array}$ & $\begin{array}{l}0.47^{* *} \\
(0.20)\end{array}$ \\
\hline Traditional materials index & $\begin{array}{c}0.12 \\
(0.14)\end{array}$ & $\begin{array}{l}-0.12 \\
(0.20)\end{array}$ & $\begin{array}{l}0.26^{* *} \\
(0.11)\end{array}$ & $\begin{array}{l}-0.20 \\
(0.18)\end{array}$ \\
\hline Modern materials index & $\begin{array}{c}-0.06 \\
(0.14)\end{array}$ & $\begin{array}{c}0.03 \\
(0.23)\end{array}$ & $\begin{array}{c}0.09 \\
(0.11)\end{array}$ & $\begin{array}{c}0.58^{* * *} \\
(0.20)\end{array}$ \\
\hline
\end{tabular}




\section{Appendices}

Table A.1: Estimated coefficients of student characteristics (Teaching practices)

\begin{tabular}{|c|c|c|c|c|c|c|}
\hline & \multicolumn{3}{|c|}{ Tutor's answers } & \multicolumn{3}{|c|}{ Students' answers } \\
\hline & Pool & Maths & Reading & Pool & Maths & Reading \\
\hline \multirow[t]{2}{*}{ Female } & -0.01 & $-0.13^{* * *}$ & $0.11^{* * *}$ & -0.02 & $-0.14^{* * *}$ & $0.10^{* * *}$ \\
\hline & $(0.02)$ & $(0.02)$ & $(0.02)$ & $(0.02)$ & $(0.02)$ & $(0.02)$ \\
\hline \multirow[t]{2}{*}{ Repeater } & $-0.37^{* * *}$ & $-0.33^{* * *}$ & $-0.41^{* * *}$ & $-0.39^{* * *}$ & $-0.37^{* * *}$ & $-0.41^{* * *}$ \\
\hline & $(0.03)$ & $(0.04)$ & $(0.04)$ & $(0.03)$ & $(0.04)$ & $(0.04)$ \\
\hline \multirow[t]{2}{*}{ Single-parent household } & $-0.05^{*}$ & -0.04 & $-0.07^{*}$ & $-0.06^{* *}$ & -0.03 & $-0.09^{* *}$ \\
\hline & $(0.03)$ & $(0.03)$ & $(0.04)$ & $(0.03)$ & $(0.04)$ & $(0.04)$ \\
\hline \multirow[t]{2}{*}{ Siblings } & $-0.05^{* * *}$ & -0.03 & $-0.08^{* * *}$ & $-0.05^{* *}$ & -0.02 & $-0.07^{* * *}$ \\
\hline & $(0.02)$ & $(0.02)$ & $(0.02)$ & $(0.02)$ & $(0.02)$ & $(0.03)$ \\
\hline \multirow[t]{2}{*}{ Born in 4th quarter } & $-0.15^{* * *}$ & $-0.15^{* * *}$ & $-0.15^{* * *}$ & $-0.15^{* * *}$ & $-0.15^{* * *}$ & $-0.14^{* * *}$ \\
\hline & $(0.02)$ & $(0.02)$ & $(0.02)$ & $(0.02)$ & $(0.02)$ & $(0.02)$ \\
\hline \multicolumn{7}{|c|}{ Age at starting school (ref: $\leq 2$ years old): } \\
\hline \multirow[t]{2}{*}{3 years old } & $-0.03^{*}$ & -0.02 & $-0.04^{* *}$ & $-0.03^{*}$ & -0.02 & $-0.04^{* *}$ \\
\hline & $(0.02)$ & $(0.02)$ & $(0.02)$ & $(0.02)$ & $(0.02)$ & $(0.02)$ \\
\hline \multirow[t]{2}{*}{4 years old } & $-0.09^{*}$ & -0.09 & -0.09 & -0.08 & -0.08 & -0.08 \\
\hline & $(0.05)$ & $(0.06)$ & $(0.06)$ & $(0.05)$ & $(0.06)$ & $(0.06)$ \\
\hline \multirow[t]{2}{*}{5 years old } & $-0.17^{* * *}$ & -0.08 & $-0.26^{* * *}$ & $-0.18^{* *}$ & -0.09 & $-0.26^{* * *}$ \\
\hline & $(0.06)$ & $(0.08)$ & $(0.08)$ & $(0.07)$ & $(0.10)$ & $(0.09)$ \\
\hline \multirow[t]{2}{*}{6 years old } & $-0.38^{* * *}$ & $-0.26^{* *}$ & $-0.49^{* * *}$ & $-0.35^{* * *}$ & $-0.22^{*}$ & $-0.49^{* * *}$ \\
\hline & $(0.09)$ & $(0.12)$ & $(0.10)$ & $(0.10)$ & $(0.13)$ & $(0.11)$ \\
\hline \multicolumn{7}{|c|}{ Country of origin (ref: Spain): } \\
\hline \multirow[t]{2}{*}{ Western Europe } & -0.04 & $0.28^{*}$ & $-0.37^{* *}$ & 0.02 & $0.35^{* *}$ & -0.31 \\
\hline & $(0.12)$ & $(0.14)$ & $(0.18)$ & $(0.13)$ & $(0.16)$ & $(0.19)$ \\
\hline \multirow[t]{2}{*}{ Non-Western Europe } & $-0.17^{* * *}$ & $-0.13^{*}$ & $-0.21^{* * *}$ & $-0.19^{* * *}$ & $-0.16^{* *}$ & $-0.23^{* * *}$ \\
\hline & $(0.05)$ & $(0.07)$ & $(0.06)$ & $(0.05)$ & $(0.07)$ & $(0.07)$ \\
\hline \multirow[t]{2}{*}{ Morocco } & $-0.16^{*}$ & -0.07 & $-0.24^{* *}$ & -0.08 & -0.02 & -0.15 \\
\hline & $(0.09)$ & $(0.11)$ & $(0.11)$ & $(0.09)$ & $(0.11)$ & $(0.12)$ \\
\hline \multirow[t]{2}{*}{ Latin America } & $-0.22^{* * *}$ & $-0.22^{* * *}$ & $-0.23^{* * *}$ & $-0.23^{* * *}$ & $-0.23^{* * *}$ & $-0.24^{* * *}$ \\
\hline & $(0.04)$ & $(0.05)$ & $(0.05)$ & $(0.04)$ & $(0.05)$ & $(0.05)$ \\
\hline \multirow[t]{2}{*}{ Asia } & $-0.26^{*}$ & -0.14 & $-0.38^{* *}$ & -0.23 & -0.06 & $-0.40^{* *}$ \\
\hline & $(0.15)$ & $(0.23)$ & $(0.17)$ & $(0.16)$ & $(0.23)$ & $(0.19)$ \\
\hline \multirow[t]{2}{*}{ Other } & $-0.29^{* *}$ & $-0.25^{*}$ & $-0.33^{* *}$ & $-0.29^{* *}$ & $-0.26^{*}$ & $-0.32^{* *}$ \\
\hline & $(0.12)$ & $(0.13)$ & $(0.14)$ & $(0.14)$ & $(0.15)$ & $(0.16)$ \\
\hline \multicolumn{7}{|c|}{ Mother's education (ref: Primary or less): } \\
\hline \multirow[t]{2}{*}{ Compulsory } & $0.10^{* * *}$ & $0.10^{* * *}$ & $0.10^{* * *}$ & $0.09^{* * *}$ & $0.08^{* *}$ & $0.09^{* *}$ \\
\hline & $(0.03)$ & $(0.03)$ & $(0.04)$ & $(0.03)$ & $(0.04)$ & $(0.04)$ \\
\hline
\end{tabular}




\begin{tabular}{|c|c|c|c|c|c|c|}
\hline & \multicolumn{3}{|c|}{ Tutor's answers } & \multicolumn{3}{|c|}{ Students' answers } \\
\hline & Pool & Maths & Reading & Pool & Maths & Reading \\
\hline High School & $\begin{array}{c}0.19^{* * *} \\
(0.03)\end{array}$ & $\begin{array}{c}0.16^{* * *} \\
(0.04)\end{array}$ & $\begin{array}{c}0.22^{* * *} \\
(0.04)\end{array}$ & $\begin{array}{c}0.19^{* * *} \\
(0.03)\end{array}$ & $\begin{array}{c}0.16^{* * *} \\
(0.04)\end{array}$ & $\begin{array}{c}0.23^{* * *} \\
(0.04)\end{array}$ \\
\hline Vocational training & $\begin{array}{c}0.15^{* * *} \\
(0.03)\end{array}$ & $\begin{array}{c}0.15^{* * *} \\
(0.04)\end{array}$ & $\begin{array}{c}0.15^{* * *} \\
(0.04)\end{array}$ & $\begin{array}{c}0.16^{* * *} \\
(0.03)\end{array}$ & $\begin{array}{c}0.15^{* * *} \\
(0.04)\end{array}$ & $\begin{array}{c}0.16^{* * *} \\
(0.04)\end{array}$ \\
\hline University & $\begin{array}{c}0.34^{* * *} \\
(0.03)\end{array}$ & $\begin{array}{c}0.34^{* * *} \\
(0.04)\end{array}$ & $\begin{array}{c}0.33^{* * *} \\
(0.04)\end{array}$ & $\begin{array}{c}0.33^{* * *} \\
(0.04)\end{array}$ & $\begin{array}{c}0.33^{* * *} \\
(0.04)\end{array}$ & $\begin{array}{c}0.32^{* * *} \\
(0.04)\end{array}$ \\
\hline \multicolumn{7}{|c|}{ Mother's labor status (ref: Self-employed): } \\
\hline Employee & $\begin{array}{l}0.05^{* *} \\
(0.02)\end{array}$ & $\begin{array}{c}0.05^{*} \\
(0.03)\end{array}$ & $\begin{array}{l}0.05^{* *} \\
(0.03)\end{array}$ & $\begin{array}{l}0.05^{* *} \\
(0.02)\end{array}$ & $\begin{array}{c}0.04 \\
(0.03)\end{array}$ & $\begin{array}{c}0.05^{*} \\
(0.03)\end{array}$ \\
\hline Unemployed & $\begin{array}{c}0.03 \\
(0.03)\end{array}$ & $\begin{array}{c}0.03 \\
(0.03)\end{array}$ & $\begin{array}{c}0.03 \\
(0.04)\end{array}$ & $\begin{array}{c}0.03 \\
(0.03)\end{array}$ & $\begin{array}{c}0.02 \\
(0.04)\end{array}$ & $\begin{array}{c}0.04 \\
(0.04)\end{array}$ \\
\hline Inactive & $\begin{array}{c}0.02 \\
(0.02)\end{array}$ & $\begin{array}{c}0.03 \\
(0.03)\end{array}$ & $\begin{array}{c}0.01 \\
(0.03)\end{array}$ & $\begin{array}{c}0.02 \\
(0.03)\end{array}$ & $\begin{array}{c}0.03 \\
(0.03)\end{array}$ & $\begin{array}{c}0.00 \\
(0.03)\end{array}$ \\
\hline \multicolumn{7}{|c|}{ Father's education (ref: Primary or less): } \\
\hline Compulsory & $\begin{array}{c}0.08^{* * *} \\
(0.03)\end{array}$ & $\begin{array}{l}0.05^{*} \\
(0.03)\end{array}$ & $\begin{array}{c}0.10^{* * *} \\
(0.03)\end{array}$ & $\begin{array}{l}0.05^{* *} \\
(0.03)\end{array}$ & $\begin{array}{c}0.04 \\
(0.03)\end{array}$ & $\begin{array}{l}0.07^{* *} \\
(0.03)\end{array}$ \\
\hline High School & $\begin{array}{c}0.22^{* * *} \\
(0.03)\end{array}$ & $\begin{array}{c}0.18^{* * *} \\
(0.04)\end{array}$ & $\begin{array}{c}0.26^{* * *} \\
(0.04)\end{array}$ & $\begin{array}{c}0.19^{* * *} \\
(0.03)\end{array}$ & $\begin{array}{c}0.16^{* * *} \\
(0.04)\end{array}$ & $\begin{array}{c}0.23^{* * *} \\
(0.04)\end{array}$ \\
\hline Vocational training & $\begin{array}{c}0.17^{* * *} \\
(0.03)\end{array}$ & $\begin{array}{c}0.15^{* * *} \\
(0.03)\end{array}$ & $\begin{array}{c}0.19^{* * *} \\
(0.03)\end{array}$ & $\begin{array}{c}0.15^{* * *} \\
(0.03)\end{array}$ & $\begin{array}{c}0.14^{* * *} \\
(0.04)\end{array}$ & $\begin{array}{c}0.16^{* * *} \\
(0.04)\end{array}$ \\
\hline University & $\begin{array}{c}0.32^{* * *} \\
(0.03)\end{array}$ & $\begin{array}{c}0.28^{* * *} \\
(0.04)\end{array}$ & $\begin{array}{c}0.35^{* * *} \\
(0.03)\end{array}$ & $\begin{array}{c}0.29^{* * *} \\
(0.03)\end{array}$ & $\begin{array}{c}0.25^{* * *} \\
(0.04)\end{array}$ & $\begin{array}{c}0.32^{* * *} \\
(0.04)\end{array}$ \\
\hline \multicolumn{7}{|c|}{ Father's labor status (ref: Self-employed): } \\
\hline Employee & $\begin{array}{l}-0.00 \\
(0.02)\end{array}$ & $\begin{array}{l}-0.01 \\
(0.02)\end{array}$ & $\begin{array}{c}0.01 \\
(0.02)\end{array}$ & $\begin{array}{l}-0.01 \\
(0.02)\end{array}$ & $\begin{array}{l}-0.02 \\
(0.02)\end{array}$ & $\begin{array}{c}0.00 \\
(0.02)\end{array}$ \\
\hline Unemployed & $\begin{array}{l}-0.03 \\
(0.03)\end{array}$ & $\begin{array}{l}-0.06 \\
(0.04)\end{array}$ & $\begin{array}{l}-0.00 \\
(0.04)\end{array}$ & $\begin{array}{l}-0.05 \\
(0.03)\end{array}$ & $\begin{array}{l}-0.08^{*} \\
(0.04)\end{array}$ & $\begin{array}{l}-0.01 \\
(0.04)\end{array}$ \\
\hline Inactive & $\begin{array}{l}-0.03 \\
(0.05)\end{array}$ & $\begin{array}{l}-0.05 \\
(0.07)\end{array}$ & $\begin{array}{l}-0.01 \\
(0.06)\end{array}$ & $\begin{array}{l}-0.04 \\
(0.05)\end{array}$ & $\begin{array}{l}-0.04 \\
(0.07)\end{array}$ & $\begin{array}{l}-0.04 \\
(0.07)\end{array}$ \\
\hline \multicolumn{7}{|l|}{ Help with homework: } \\
\hline Private tutor & $\begin{array}{c}-0.43^{* * *} \\
(0.02)\end{array}$ & $\begin{array}{c}-0.41^{* * * *} \\
(0.03)\end{array}$ & $\begin{array}{c}-0.45^{* * *} \\
(0.03)\end{array}$ & $\begin{array}{c}-0.42^{* * *} \\
(0.03)\end{array}$ & $\begin{array}{c}-0.40^{* * *} \\
(0.03)\end{array}$ & $\begin{array}{c}-0.44^{* * *} \\
(0.03)\end{array}$ \\
\hline Family & $\begin{array}{c}-0.09^{* * *} \\
(0.02)\end{array}$ & $\begin{array}{c}-0.12^{* * *} \\
(0.02)\end{array}$ & $\begin{array}{c}-0.06^{* * *} \\
(0.02)\end{array}$ & $\begin{array}{c}-0.09^{* * *} \\
(0.02)\end{array}$ & $\begin{array}{c}-0.12^{* * *} \\
(0.02)\end{array}$ & $\begin{array}{c}-0.05^{* * *} \\
(0.02)\end{array}$ \\
\hline Constant & $\begin{array}{c}0.37 \\
(0.25)\end{array}$ & $\begin{array}{l}0.52^{*} \\
(0.31)\end{array}$ & $\begin{array}{c}0.22 \\
(0.28)\end{array}$ & $\begin{array}{c}0.73^{* * *} \\
(0.27)\end{array}$ & $\begin{array}{l}0.77^{* *} \\
(0.35)\end{array}$ & $\begin{array}{l}0.69^{* *} \\
(0.30)\end{array}$ \\
\hline School FE & Yes & Yes & Yes & Yes & Yes & Yes \\
\hline Teacher characteristics & Yes & Yes & Yes & Yes & Yes & Yes \\
\hline Observations & 22826 & 11413 & 11413 & 20900 & 10450 & 10450 \\
\hline$R^{2}$ & 0.22 & 0.23 & 0.24 & 0.21 & 0.23 & 0.23 \\
\hline
\end{tabular}


Table A.2: Estimated coefficients of student characteristics (Teaching materials)

\begin{tabular}{|c|c|c|c|c|c|c|}
\hline & \multicolumn{3}{|c|}{ Tutor's answers } & \multicolumn{3}{|c|}{ Students' answers } \\
\hline & Pool & Maths & Reading & Pool & Maths & Reading \\
\hline \multirow[t]{2}{*}{ Female } & -0.01 & $-0.13^{* * *}$ & $0.11^{* * *}$ & -0.02 & $-0.14^{* * *}$ & $0.10^{* * *}$ \\
\hline & $(0.02)$ & $(0.02)$ & $(0.02)$ & $(0.02)$ & $(0.02)$ & $(0.02)$ \\
\hline \multirow[t]{2}{*}{ Repeater } & $-0.37^{* * *}$ & $-0.33^{* * *}$ & $-0.41^{* * *}$ & $-0.39^{* * *}$ & $-0.36^{* * *}$ & $-0.42^{* * *}$ \\
\hline & $(0.03)$ & $(0.04)$ & $(0.04)$ & $(0.03)$ & $(0.04)$ & $(0.04)$ \\
\hline \multirow[t]{2}{*}{ Single-parent household } & $-0.05^{*}$ & -0.04 & $-0.07^{*}$ & $-0.05^{*}$ & -0.03 & $-0.07^{*}$ \\
\hline & $(0.03)$ & $(0.03)$ & $(0.04)$ & $(0.03)$ & $(0.03)$ & $(0.04)$ \\
\hline \multirow[t]{2}{*}{ Siblings } & $-0.05^{* *}$ & -0.03 & $-0.08^{* * *}$ & $-0.05^{* *}$ & -0.02 & $-0.07^{* * *}$ \\
\hline & $(0.02)$ & $(0.02)$ & $(0.02)$ & $(0.02)$ & $(0.02)$ & $(0.03)$ \\
\hline \multicolumn{7}{|c|}{ Age at starting school (ref: $\leq 2$ years old): } \\
\hline \multirow[t]{2}{*}{3 years old } & $-0.03^{*}$ & -0.02 & $-0.04^{* *}$ & -0.02 & -0.02 & -0.03 \\
\hline & $(0.02)$ & $(0.02)$ & $(0.02)$ & $(0.02)$ & $(0.02)$ & $(0.02)$ \\
\hline \multirow[t]{2}{*}{4 years old } & $-0.09^{*}$ & -0.09 & -0.08 & $-0.09^{*}$ & -0.09 & -0.09 \\
\hline & $(0.05)$ & $(0.06)$ & $(0.06)$ & $(0.05)$ & $(0.06)$ & $(0.06)$ \\
\hline \multirow[t]{2}{*}{5 years old } & $-0.17^{* * *}$ & -0.08 & $-0.26^{* * *}$ & $-0.20^{* * *}$ & -0.11 & $-0.28^{* * *}$ \\
\hline & $(0.06)$ & $(0.08)$ & $(0.08)$ & $(0.07)$ & $(0.09)$ & $(0.08)$ \\
\hline \multirow[t]{2}{*}{6 years old } & $-0.38^{* * *}$ & $-0.26^{* *}$ & $-0.49^{* * *}$ & $-0.40^{* * *}$ & $-0.30^{* *}$ & $-0.50^{* * *}$ \\
\hline & $(0.09)$ & $(0.12)$ & $(0.10)$ & $(0.10)$ & $(0.13)$ & $(0.11)$ \\
\hline \multirow[t]{2}{*}{ Born in 4th quarter } & $-0.15^{* * *}$ & $-0.15^{* * *}$ & $-0.15^{* * *}$ & $-0.15^{* * *}$ & $-0.15^{* * *}$ & $-0.15^{* * *}$ \\
\hline & $(0.02)$ & $(0.02)$ & $(0.02)$ & $(0.02)$ & $(0.02)$ & $(0.02)$ \\
\hline \multicolumn{7}{|c|}{ Country of origin (ref: Spain): } \\
\hline \multirow[t]{2}{*}{ Western Europe } & -0.05 & $0.28^{*}$ & $-0.38^{* *}$ & -0.01 & $0.31^{* *}$ & $-0.33^{*}$ \\
\hline & $(0.12)$ & $(0.14)$ & $(0.18)$ & $(0.12)$ & $(0.15)$ & $(0.18)$ \\
\hline \multirow[t]{2}{*}{ Non-Western Europe } & $-0.17^{* * *}$ & $-0.13^{*}$ & $-0.21^{* * *}$ & $-0.16^{* * *}$ & -0.11 & $-0.21^{* * *}$ \\
\hline & $(0.05)$ & $(0.07)$ & $(0.06)$ & $(0.05)$ & $(0.07)$ & $(0.07)$ \\
\hline \multirow[t]{2}{*}{ Morocco } & $-0.16^{*}$ & -0.07 & $-0.24^{* *}$ & -0.16 & -0.08 & $-0.24^{* *}$ \\
\hline & $(0.09)$ & $(0.11)$ & $(0.11)$ & $(0.10)$ & $(0.11)$ & $(0.12)$ \\
\hline \multirow[t]{2}{*}{ Latin America } & $-0.22^{* * *}$ & $-0.22^{* * *}$ & $-0.23^{* * *}$ & $-0.22^{* * *}$ & $-0.20^{* * *}$ & $-0.24^{* * *}$ \\
\hline & $(0.04)$ & $(0.05)$ & $(0.05)$ & $(0.04)$ & $(0.05)$ & $(0.05)$ \\
\hline \multirow[t]{2}{*}{ Asia } & $-0.27^{*}$ & -0.14 & $-0.40^{* *}$ & -0.23 & -0.06 & $-0.40^{* *}$ \\
\hline & $(0.15)$ & $(0.22)$ & $(0.17)$ & $(0.15)$ & $(0.23)$ & $(0.18)$ \\
\hline \multirow[t]{2}{*}{ Other } & $-0.28^{* *}$ & $-0.24^{*}$ & $-0.32^{* *}$ & $-0.28^{* *}$ & $-0.26^{*}$ & $-0.31^{*}$ \\
\hline & $(0.12)$ & $(0.13)$ & $(0.15)$ & $(0.13)$ & $(0.14)$ & $(0.16)$ \\
\hline \multicolumn{7}{|c|}{ Mother's education (ref: Primary or less): } \\
\hline \multirow[t]{2}{*}{ Compulsory } & $0.10^{* * *}$ & $0.10^{* * *}$ & $0.10^{* * *}$ & $0.08^{* * *}$ & $0.08^{* *}$ & $0.08^{* *}$ \\
\hline & $(0.03)$ & $(0.03)$ & $(0.04)$ & $(0.03)$ & $(0.04)$ & $(0.04)$ \\
\hline \multirow[t]{2}{*}{ High School } & $0.19^{* * *}$ & $0.16^{* * *}$ & $0.22^{* * *}$ & $0.18^{* * *}$ & $0.14^{* * *}$ & $0.22^{* * *}$ \\
\hline & $(0.03)$ & $(0.04)$ & $(0.04)$ & $(0.03)$ & $(0.04)$ & $(0.04)$ \\
\hline \multirow[t]{2}{*}{ Vocational training } & $0.15^{* * *}$ & $0.15^{* * *}$ & $0.15^{* * *}$ & $0.14^{* * *}$ & $0.13^{* * *}$ & $0.15^{* * *}$ \\
\hline & $(0.03)$ & $(0.04)$ & $(0.04)$ & $(0.03)$ & $(0.04)$ & $(0.04)$ \\
\hline University & $0.34^{* * *}$ & $0.34^{* * *}$ & $0.33^{* * *}$ & $0.32^{* * *}$ & $0.31^{* * *}$ & $0.32^{* * *}$ \\
\hline & $(0.03)$ & $(0.04)$ & $(0.04)$ & $(0.04)$ & $(0.04)$ & $(0.04)$ \\
\hline Mother's labor status (re & Self-em & loyed): & & & & \\
\hline
\end{tabular}




\begin{tabular}{lccc|ccc}
\hline & \multicolumn{3}{c}{ Tutor's answers } & \multicolumn{3}{c}{ Students' answers } \\
\cline { 2 - 7 } & Pool & Maths & Reading & Pool & Maths & Reading \\
\hline Employee & $0.05^{* *}$ & $0.05^{*}$ & $0.05^{* *}$ & $0.05^{* *}$ & 0.04 & $0.06^{* *}$ \\
& $(0.02)$ & $(0.03)$ & $(0.03)$ & $(0.02)$ & $(0.03)$ & $(0.03)$ \\
Unemployed & 0.03 & 0.03 & 0.03 & 0.04 & 0.04 & 0.03 \\
& $(0.03)$ & $(0.03)$ & $(0.04)$ & $(0.03)$ & $(0.04)$ & $(0.04)$ \\
Inactive & 0.02 & 0.03 & 0.01 & 0.02 & 0.02 & 0.01 \\
& $(0.02)$ & $(0.03)$ & $(0.03)$ & $(0.03)$ & $(0.03)$ & $(0.03)$ \\
Father's education (ref: & Primary or & less): & & & & \\
Compulsory & $0.08^{* * *}$ & 0.05 & $0.10^{* * *}$ & $0.05^{* *}$ & 0.04 & $0.07^{* *}$ \\
& $(0.03)$ & $(0.03)$ & $(0.03)$ & $(0.03)$ & $(0.03)$ & $(0.03)$ \\
High School & $0.21^{* * *}$ & $0.18^{* * *}$ & $0.25^{* * *}$ & $0.20^{* * *}$ & $0.16^{* * *}$ & $0.23^{* * *}$ \\
& $(0.03)$ & $(0.04)$ & $(0.04)$ & $(0.03)$ & $(0.04)$ & $(0.04)$ \\
Vocational training & $0.17^{* * *}$ & $0.15^{* * *}$ & $0.19^{* * *}$ & $0.15^{* * *}$ & $0.14^{* * *}$ & $0.16^{* * *}$ \\
University & $(0.03)$ & $(0.03)$ & $(0.03)$ & $(0.03)$ & $(0.04)$ & $(0.03)$ \\
Father's labor status & $0.31^{* * *}$ & $0.28^{* * *}$ & $0.35^{* * *}$ & $0.30^{* * *}$ & $0.27^{* * *}$ & $0.33^{* * *}$ \\
Employee & $(0.03)$ & $(0.04)$ & $(0.03)$ & $(0.03)$ & $(0.04)$ & $(0.03)$ \\
& -0.00 & -0.01 & 0.01 & -0.01 & -0.02 & 0.01 \\
Unemployed & $(0.02)$ & $(0.02)$ & $(0.02)$ & $(0.02)$ & $(0.02)$ & $(0.02)$ \\
Inactive & -0.03 & -0.06 & -0.01 & -0.04 & $-0.08^{*}$ & 0.00 \\
Help with homework: & $(0.03)$ & $(0.04)$ & $(0.04)$ & $(0.03)$ & $(0.04)$ & $(0.04)$ \\
Private tutor & -0.03 & -0.05 & -0.01 & -0.04 & -0.07 & -0.00 \\
Family & $(0.05)$ & $(0.07)$ & $(0.06)$ & $(0.05)$ & $(0.07)$ & $(0.06)$ \\
Constant & $-0.43^{* * *}$ & $-0.41^{* * *}$ & $-0.45^{* * *}$ & $-0.43^{* * *}$ & $-0.41^{* * *}$ & $-0.44^{* * *}$ \\
& $(0.02)$ & $(0.03)$ & $(0.03)$ & $(0.03)$ & $(0.03)$ & $(0.03)$ \\
School FE & $-0.09^{* * *}$ & $-0.12^{* * *}$ & $-0.06^{* * *}$ & $-0.09^{* * *}$ & $-0.13^{* * *}$ & $-0.05^{* * *}$ \\
Observations & $(0.02)$ & $(0.02)$ & $(0.02)$ & $(0.02)$ & $(0.02)$ & $(0.02)$ \\
$R^{2}$ & 0.40 & $0.59^{*}$ & 0.21 & $0.49^{*}$ & $0.69^{* *}$ & 0.29 \\
Standard errors clustered at school level in parentheses. ${ }^{*} p$ & $<0.10,^{* *}$ & $p<0.05,{ }^{* * *} p<0.01$.
\end{tabular}


Table B.1: Teacher-student indexes gap

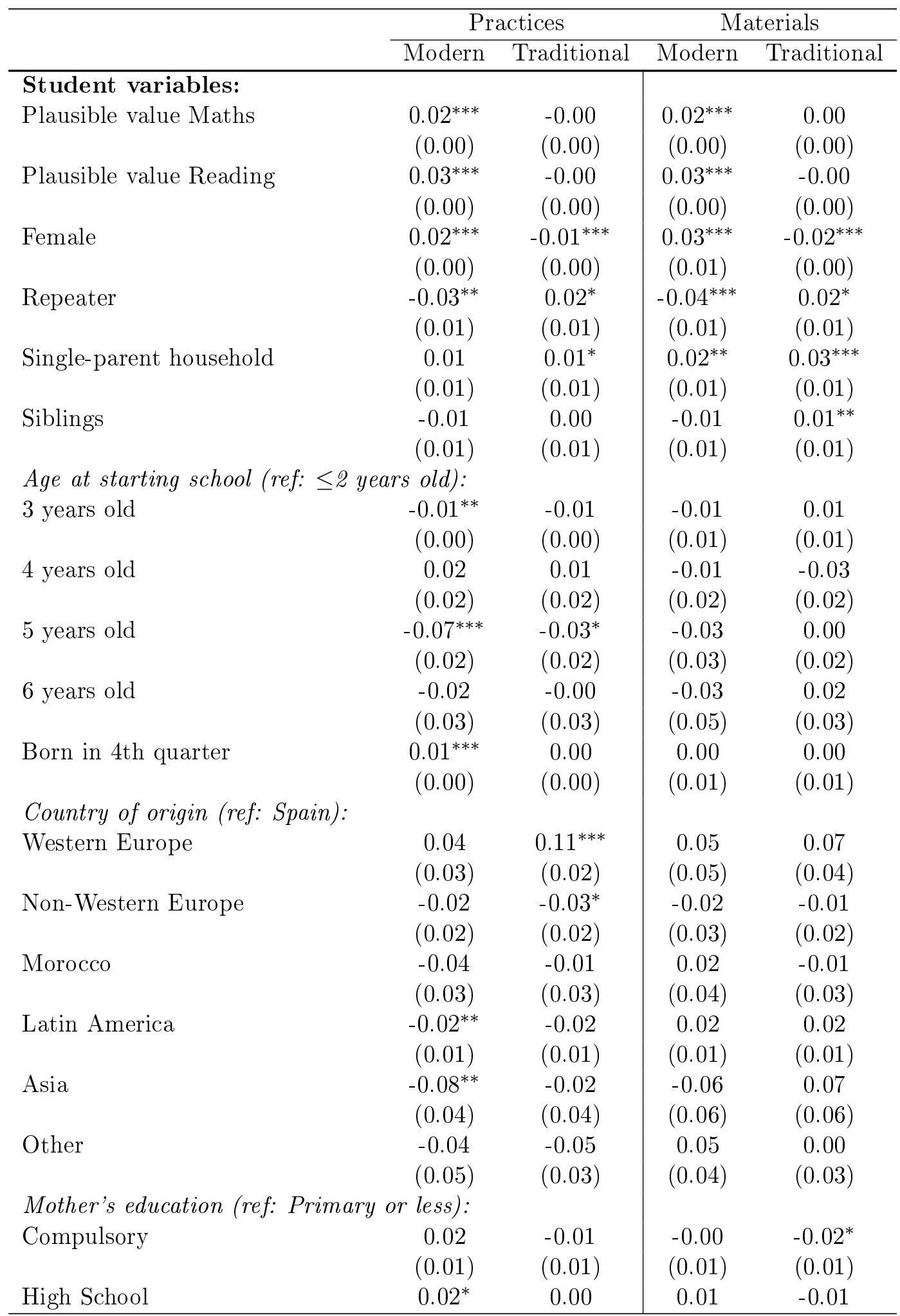

Dependent variable: difference in tutor and student indexes. Standard errors clustered at school level in parentheses. ${ }^{*} p<0.10,{ }^{* *} p<0.05,{ }^{* * *} p<0.01$.

(Continued on next page) 


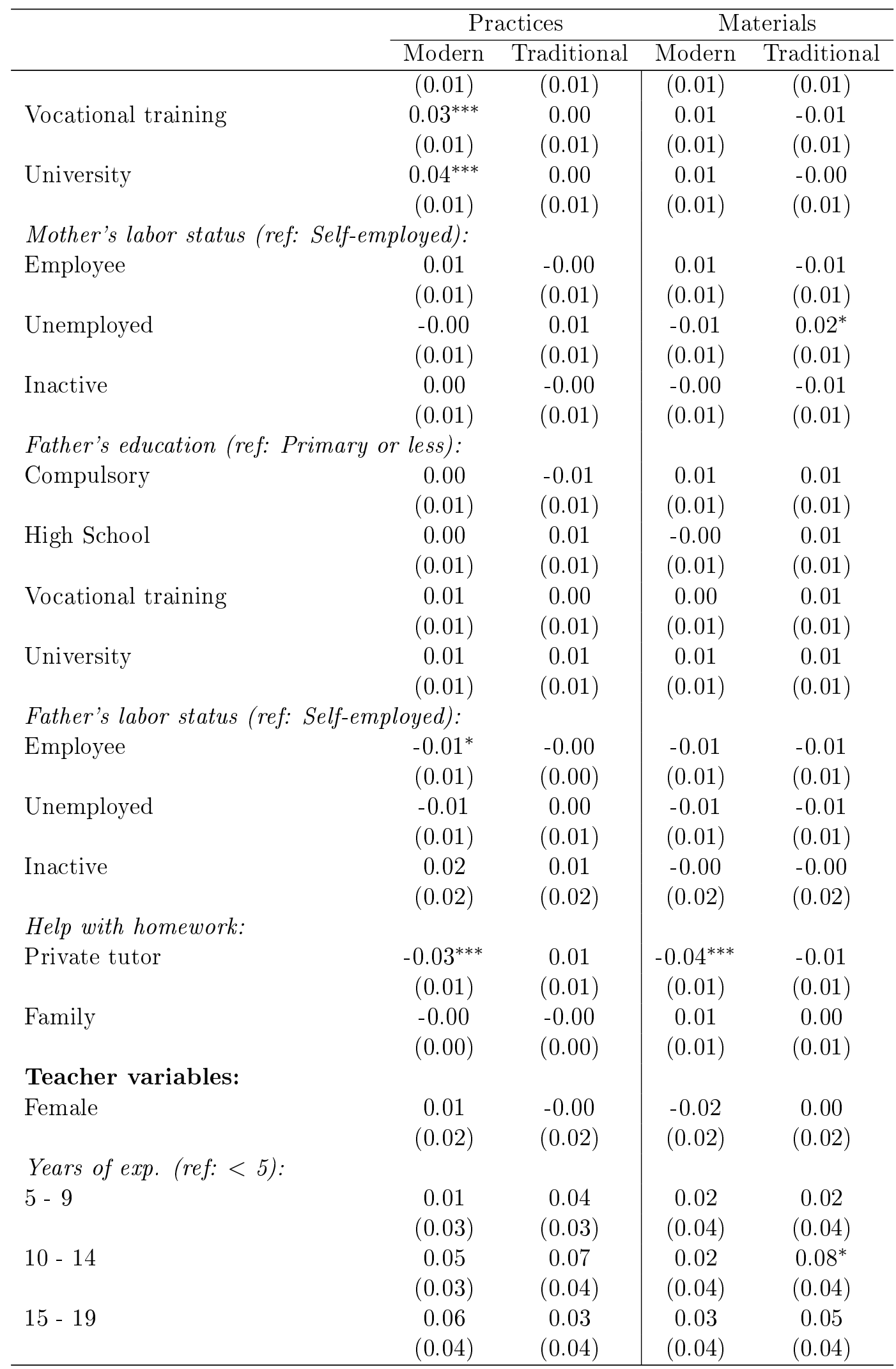

Dependent variable: difference in tutor and student indexes. Standard errors clustered at school level in parentheses. ${ }^{*} p<0.10,{ }^{* *} p<0.05,{ }^{* * *} p<0.01$.

(Continued on next page) 


\begin{tabular}{|c|c|c|c|c|}
\hline & \multicolumn{2}{|c|}{ Practices } & \multicolumn{2}{|c|}{ Materials } \\
\hline & Modern & Traditional & Modern & Traditional \\
\hline \multirow[t]{2}{*}{$20-24$} & 0.03 & 0.03 & 0.02 & -0.01 \\
\hline & $(0.03)$ & $(0.03)$ & $(0.04)$ & $(0.04)$ \\
\hline \multirow[t]{2}{*}{$25-29$} & 0.04 & 0.03 & 0.05 & -0.01 \\
\hline & $(0.03)$ & $(0.03)$ & $(0.04)$ & $(0.04)$ \\
\hline \multirow[t]{2}{*}{30 or more } & $0.05^{*}$ & 0.03 & 0.02 & 0.05 \\
\hline & $(0.03)$ & $(0.03)$ & $(0.04)$ & $(0.03)$ \\
\hline \multirow[t]{2}{*}{ 5-years degree or more } & -0.01 & -0.03 & -0.00 & -0.03 \\
\hline & $(0.02)$ & $(0.02)$ & $(0.02)$ & $(0.02)$ \\
\hline \multicolumn{5}{|l|}{ Taught subjects (ref: Maths): } \\
\hline \multirow{2}{*}{ Reading and Maths } & -0.02 & 0.03 & -0.02 & 0.01 \\
\hline & $(0.03)$ & $(0.05)$ & $(0.04)$ & $(0.03)$ \\
\hline \multirow[t]{2}{*}{ Reading } & -0.01 & 0.02 & -0.02 & 0.04 \\
\hline & $(0.05)$ & $(0.07)$ & $(0.04)$ & $(0.04)$ \\
\hline \multicolumn{5}{|l|}{ Person asking for a meeting: } \\
\hline \multirow[t]{2}{*}{ Parents } & -0.02 & 0.01 & 0.00 & 0.04 \\
\hline & $(0.02)$ & $(0.03)$ & $(0.02)$ & $(0.03)$ \\
\hline \multirow[t]{2}{*}{ Teacher } & -0.02 & -0.00 & $-0.04^{* *}$ & 0.01 \\
\hline & $(0.02)$ & $(0.02)$ & $(0.02)$ & $(0.03)$ \\
\hline \multirow[t]{2}{*}{ Number of meetings with parents } & -0.01 & $0.03^{*}$ & 0.02 & 0.01 \\
\hline & $(0.01)$ & $(0.02)$ & $(0.02)$ & $(0.02)$ \\
\hline \multirow[t]{2}{*}{ Teacher at $3^{r d}$ and $4^{\text {th }}$ grades } & $-0.04^{* *}$ & -0.02 & -0.01 & -0.01 \\
\hline & $(0.02)$ & $(0.02)$ & $(0.02)$ & $(0.02)$ \\
\hline \multirow[t]{2}{*}{ Class size } & 0.00 & -0.00 & -0.00 & 0.00 \\
\hline & $(0.00)$ & $(0.00)$ & $(0.00)$ & $(0.01)$ \\
\hline \multirow[t]{2}{*}{ Public school } & $-0.33^{* * *}$ & $-0.17^{* * *}$ & $0.07^{*}$ & $-0.35^{* * *}$ \\
\hline & $(0.04)$ & $(0.04)$ & $(0.04)$ & $(0.06)$ \\
\hline \multirow[t]{2}{*}{ Constant } & 0.12 & $-0.33^{* *}$ & 0.10 & -0.05 \\
\hline & $(0.12)$ & $(0.15)$ & $(0.13)$ & $(0.15)$ \\
\hline School FE & Yes & Yes & Yes & Yes \\
\hline Observations & 10691 & 10762 & 10742 & 11010 \\
\hline$R^{2}$ & 0.28 & 0.30 & 0.27 & 0.37 \\
\hline
\end{tabular}

Dependent variable: difference in tutor and student indexes. Standard errors clustered at school level in parentheses. ${ }^{*} p<0.10,{ }^{* *} p<0.05,{ }^{* * *} p<0.01$. 